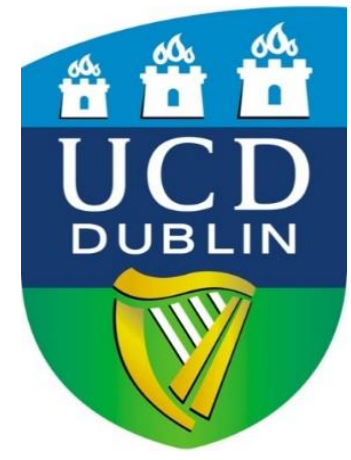

UCD GEARY INSTITUTE FOR PUBLIC POLICY

DISCUSSION PAPER SERIES

\title{
Oil Price Volatility and Political Unrest: \\ Prudence and Protest in Producer and Consumer Societies, 1980-2013
}

\author{
Krishna Chaitanya Vadlamannati \\ School of Politics \& International Relations (SPIRe) \\ University College Dublin (UCD), Ireland \\ Indra de Soysa \\ Department of Sociology and Political Science (ISS) \\ Norwegian University of Science and Technology (NTNU) \\ Trondheim, Norway
}

Geary WP2019/08

April 9, 2019

UCD Geary Institute Discussion Papers often represent preliminary work and are circulated to encourage discussion. Citation of such a paper should account for its provisional character. A revised version may be available directly from the author.

Any opinions expressed here are those of the author(s) and not those of UCD Geary Institute. Research published in this series may include views on policy, but the institute itself takes no institutional policy positions. 


\begin{abstract}
Many find that oil wealth produces political conflict. It is also argued that oil makes countries susceptible to the "resource curse" because rulers more easily buy off opposition and stave off economic reforms. We explore this issue by examining whether oil price volatility affects political unrest in oil-producing and oil import dependent states. We argue that in oil-producing countries, low prices generate antigovernment protest conditional on a state's access to foreign exchange reserves that accumulate due to political prudence. We also argue that oilimporting countries are affected by high oil prices, but again, conditional on access to foreign exchange reserves, which allow government to ease the pain of austerity. Using panel data covering 165 countries between 1980-2013 (34 years), we find support for the hypotheses. Our results lend support to the view that prudent governance in oil-producer countries that resist political Dutch disease and save for rainy days are more capable of weathering low-price years. These results are in line with others that show that oil producers avoid civil war through higher public spending. The results are robust to alternative data, measurement, sample size, and estimation methods.
\end{abstract}

Key words: Oil wealth, oil price, Dutch disease, forex reserves, political unrest

\footnotetext{
${ }^{1}$ We thank Päivi Lujala, Jonathon Moses, Mike Ross, Christa Brunshewlier, Cristina Bodea, Stijn Van Weezel, Artur Tamazian, Kai Ghering, Vera Eichenauer for useful comments on the earlier version of the draft.
} 


\section{Introduction}

The question of natural resource extraction and economic and political failure is debated across many disciplines in the social sciences (Frankel 2012, Ross 2012, van der Ploeg 2011, Wenar 2016). Arguments about the exact role of natural resources in causing political violence is particularly contentious (Brunnschweiler and Bulte 2009, Collier, Hoeffler and Rohner 2009, Fearon 2005, Ross 2006). While resource wealth might encourage rapacious behaviour by rulers, which could provoke political dissent, it may also allow rulers the revenue to buy off potential challengers (Basedau and Lay 2009, Smith 2004, Thies 2010). Indeed, oil wealth may allow bad leaders to remain comfortably in office by sowing oil wealth, staving off economic reforms and repressing dissent (Acemoglu and Robinson 2012). Thus, oil wealth is also thought to encourage autocracy and reduce pressures for democracy (Diamond 2008, Ross 2001). Consider that many oil-rich states managed to weather the Arab Spring in an era of high oil prices, and the current political instability in many oil-rich states-as in Iran today-are blamed on the collapse of the oil price (Klare 2016, Ross 2011). Even in many non-oil-producing countries, political imperatives stemming from the importance of fuel for critical aspects of people's lives, such as food, cooking, and transportation, explain a variety of policy choices (Cheon, Urpelainen and Lackner 2013). While questions relating to climate change and food price shocks are heavily investigated, the question of fuel price shocks and political violence is noticeably neglected (Buhaug 2014, Hendrix and Haggard 2015, van Weezel 2016). We fill this gap in the literature by arguing that the nature of a state's response during oil price hikes in both producer and non-producer countries is dependent on the availability of foreign reserves, which is a proxy for political prudence and sound management of "Dutch disease" effects on the economy. ${ }^{2}$ Unlike all previous studies that look at violent conflict and civil war in producer countries, we examine anti-government protest, which is a precursor to armed conflict and a signal from people to states in both producer- and non-producer states, but accounting more stringently for the true financial constraints of a government to handle shocks.

Using the latest available data on anti-government protest (violent and non-violent) contained in the Cross National Time Series (CNTS) database for a sample of 165 countries between the years 1980 and 2013, we find robust evidence to suggest that oil-producing countries suffer anti-government protest conditional on low oil prices, whereas oil-import dependent states experience

\footnotetext{
${ }^{2}$ The term Dutch disease was coined to explain the variety of problems that arose in the Dutch economy after the discovery of off-shore natural gas. The uncompetitiveness of the Dutch economy was attributed to the rise of its real exchange rate relative to her trading partners.
} 
more anti-government protests during periods of high oil prices. In both cases, however, adequate foreign exchange reserves are shown to condition the likelihood of protests, suggesting a role for prudent governance for mitigating the pain of austerity during lean years. These effects, however, were less robust in the case of oil-importing countries, which are less likely in general to have had oil-based patronage spending. The results are robust against several alternative models, data, and estimating techniques, including country and time fixed effects, and analyses using instrumental variables (IV) approach for addressing endogeneity concerns. Our results generally support others that find that oil's effects on economic and political factors depend on how prudently governments deploy their rents (Auty 2001, Frankel 2012, Mehlum, Moene and Torvik 2006), a result also found in the case of larger-scale violence, such as full-blown civil war (Bodea, Higashijima and Singh 2016).

\section{Theory}

In the broadest sense, the study of oil price volatility and civil unrest is a study of income shocks on a population. One of the most noteworthy findings on the causes of civil war is that poor countries, the most susceptible countries to price shocks, show the highest risks (Collier, Hoeffler and Rohner 2009, Fearon and Laitin 2003). Many report that low economic growth causes civil war (Chassang and Padró i Miquel 2009, Miguel, Satyanath and Sergenti 2004). Others find that countries dependent on primary commodity exports experience conflict because of the volatility of commodity prices through either opportunity cost effects, or rapacity effects (Dube and Vargas 2013). The evidence from Africa suggests that negative price shocks of commodities generate civil wars in commoditydependent countries (Brückner and Ciccone 2010). Some others suggest that violence is more likely due to state capacity rather than societal grievances because shocks can constrain the choices of states highly dependent on natural resources for their revenues (Fearon 2005, Thies 2010). While many studies aggregate all commodity prices, a few studies disaggregate them. Bazzi and Blattman (2014) report no effect of price shocks on violent conflict, but they find that high prices shorten ongoing civil war, apparently because it produces greater revenues for states, which allows them to defeat rebels (Bazzi and Blattman 2014). Others report that the effect of price shocks are indeterminate because observed advantages to one party in conflict from a commodity price shock should lead to concessions by the other, but price volatility, where there is uncertainty about future prices, should predict more violence because of the commitment problem (Morgan and Reinhardt 2015).

The studies presented above essentially examine countries already in violent conflict, or they focus on how rebel strategies and state strategies 
respond to price changes. We depart from these studies in several significant ways. First, we focus on anti-government protests that may or may not be violent, moving away from looking at organized armed rebellions in terms of civil wars. Indeed, as some find, non-violent protests can sometimes be more effective at achieving reforms than violent rebellions (Chenoweth and Stephan 2011). We focus on the interaction between states and citizens, or at least social groups more broadly affected by shocks than a rebel organization, which is assumed to be dependent on controlling a lootable commodity. Anti-government protests and revolts are often precursors to organized violence and more broadly representative of a social grievance that spills over onto the streets (Chenoweth and Stephan 2011, Regan and Norton 2005). Moreover, the absence of violence despite a shock might very well be a result of a state's interventions that cauterize protest even before it galvanizes. States can either repress dissent or follow the less costly path of conceding to some policy change or reform that might be agreed upon. For instance, a state that has high savings in terms of a foreign exchange reserves might be able more effectively deal with an economic shock by committing to ease austerity, or buy off well-placed groups through patronage.

Anti-government protests occur for structural reasons, such as level of development and a lack of political rights, but there seems also to be a high degree of agency in terms of when and where they occur (Chenoweth and Ulfelder 2017). We argue that oil-rich governments face anti-government protests only when their populations face austerity, a factor determined by the oil price. Organizers of protest are likely to use this window of opportunity and reveal their private preferences when people are affected broadly (Costello, Jenkins and Aly 2015, Kuran 1995). Times of austerity also invite groups to challenge the status quo because it may signal state weakness. Administratively weak resource-dependent states facing difficulties in terms of being able to spend lavishly on patronage also invite protest from opportunistic groups when oil prices fall. Indeed, many economists recognize that prudent states are those that manage volatility of commodity prices, partly by saving for rainy days (Frankel 2012). Most importantly, however, we also examine the effects of price shocks on oil import-dependent states, which could for example lower taxes on fuel or subsidize consumers in other ways conditional on the fact that these states too have access to adequate forex reserves. Studies that pool producers and importers in their analyses are susceptible to get mixed results based on the differential effects of price shocks on these two groups. Moreover, we focus on oil price shocks because fuel, rather than any one food item or mineral, tends to have the most powerful repercussions among both producer and consumer 
economies. The degree of austerity that price shocks force on a society, we argue, will be dependent on a government's access to revenue for attenuating austerity. Empirical evidence on the natural resource curse in terms of political stability and democratization are mixed, both in terms of findings and theoretical argumentation (Basedau and Lay 2009). One argument about natural resources is that it encourages weak states, which make them pushovers when it comes to facing an organized opposition (Fearon 2005). The question then is why don't resource-wealthy states democratize more often, given that people could more easily overthrow their dictators? Others argue that a natural resource curse exists precisely because capricious rulers are able to fend off opposition and maintain their hold on power (Acemoglu and Robinson 2012, Diamond 2008, Smith 2004). Yet again, some others have argued that oil matters only after the high-price era since the 1970s, particularly since control of oil has shifted to national governments away from a few international companies (Ross 2012). These ambiguities are played out in the recent Arab Spring: some autocrats that faced protests and demonstrations succumbed while others solidified their positions, often without much violence, while others, such as Syria, descended into civil war. We submit that oil-wealthy rulers, particularly in the Gulf region especially might have been more susceptible to being ousted if not for the high oil prices they enjoyed, allowing countries such as Saudi Arabia greater leverage at home and abroad. Saudi Arabia even intervened directly in countries, such as Bahrain and Yemen. We argue that the oil price and access to forex reserves are two important conditioning factors for predicting when oil wealth leads to antigovernment protest. We also argue that high price periods might be destabilizing in many oil import dependent states, which are subject to the constraints of low forex reserves. First, however, we explain how oil matters and how political Dutch disease keeps oil-producing countries vulnerable economically to oil-price downturns.

\subsection{Why oil, and how does it matter?}

Unlike other commodities, oil is often thought to be special (Ross 2012, Wenar 2016). First, oil is a "point source" resource, which is a natural resource extracted from a concentrated geographic area (Le Billion 2001). Because of its concentrated location and the technical skills required to run the extraction process, oil is thought to be more easily monopolized than diffuse resources, which are resources that are widely spread out and might be subject to a chain of activity requiring multiple actors in the extraction and marketing process (Le Billon 2001). As such, the state is often heavily involved in the extraction process of oil, for example through state owned enterprises, where the profits, or rents accrue directly to the state. Point resources such as oil are thus thought to be 
more easily protected by a state and less exposed to looting (Bulte, Damania and Deacon 2005). These factors allow states to monopolize the revenues of oil. The political regime of oil-wealthy states, thus, are often viewed by the populace as guardians of the national wealth and the purveyors of public welfare. The characteristics of a point resource may as such increase the possibility for political instability at different levels of intensity and violence in the oil exporting country vis-à-vis diffuse resources, which may be more prone to looting and warlordism (Le Billion 2001). The point, however, is that point-source resources tie the state to welfare provision and state-led economic development, which some have termed "precocious keynseianism," which makes these states vulnerable to real and perceived economic failure (Waldner 1999).

Secondly, oil wealth tends to dominate an economy because of its relatively high value and the sheer quantities extracted. Indeed, oil and natural gas rents tend to dominate total production (gross domestic product, GDP) compared with rents from other resources on a country-year basis. ${ }^{3}$ Thirdly, oil is characterized by its price volatility because demand and supply does not remain constant. In a study of price volatility from 1945 to 2005, Regnier (2007) found that both crude oil and refined petroleum were more volatile compared with 95 percent of domestic products, according to the monthly producer price index (PPI) (Regnier 2007). ${ }^{4}$ In 2007, oil prices were more volatile than 65 percent of other primary products (Regnier 2007). The volatility of oil markets can, for the most part, be explained by the (in)elasticities of supply and demand (Hamilton 2008, Smith 2009). Elasticity of oil demand can hence be defined as "the percentage change in quantity demanded divided by the percentage change in price (...) along a given demand curve" (Hamilton 2008). At a short run elasticity estimate of about -0.05 , oil is thought to have a rather inelastic demand curve (Smith 2009). Demand is inelastic in the short run because reducing the use of oil in the production of goods require both time and access to a substitute, or a technical solution that makes oil more efficient (Smith 2009).

In other words, the cost of adjustment to oil price change is high and time-consuming. The supply of oil is also inelastic in the short run. This is because increasing the productive capacity of oil fields requires planning and technological innovation. Furthermore, the Organization of the Petroleum Exporting Countries (OPEC) has implemented policies to reduce the quantity of oil extraction as well as limiting resources devoted to finding and developing new sources, which adds to the inelasticity of supply (Smith 2009). Exporting and

\footnotetext{
3 See oil rents data reported in the World Development Indicators online database. http://data.worldbank.org/data-catalog/world-development-indicators.

4 The PPI measures the average change over time in the selling prices received by domestic producers for their output (Bureau of Labour Statistics).
} 
importing countries alike generally hold inventories, however these are not sufficient to reduce the effect of supply and demand inelasticity on the oil market (Smith 2009). Because both supply and demand are inelastic in the short run, the price must be driven much further before an equilibrium is reached. For these reasons, inelasticity of supply and demand lead to volatility in the price of oil (Smith 2009). These periods of price booms and busts are referred to as the oil price cycle, and the fluctuations in price naturally affect oil importing states as well as oil exporting states (Hunt, Isard and Laxton 2001). The next section discusses how price fluctuations can affect both exporting and importing countries.

\subsection{Oil exporters}

The oil-exporting state's woes due to oil price fluctuations stem from the difficulties of managing adverse economic effects from "Dutch disease." In essence, Dutch disease refers to how high price periods affect the non-oil tradable sectors because of a rising real-exchange rate and the shift of resources away from the tradable to the resource sector, effectively making the country more dependent on extraction and thus more vulnerable to downturns in oil prices (Auty and Gelb 2000, Sachs and Warner 1995). Because oil is a point resource, extraction is mostly managed by state-owned enterprises, causing economic influence and political power to be highly concentrated (Karl 1997). The supply of resource rents equals a non-tax revenue to the state (Ross 2012). As such, the state's political regime is tasked with managing and allocating these extra resources. How these resources are managed will be of utmost importance for the resource abundant country's development. While poor revenue management may lead to dependence upon oil and increase vulnerability to oil price fluctuations, responsible resource management can reduce symptoms of Dutch disease, and thus, reduce the dependence on oil revenue (Mehlum, Moene and Torvik 2006, Robinson, Torvik and Verdier 2006, Ross 2015). In this respect, preexisting institutions such as democracy, property rights, transparency and a functioning bureaucracy will influence the state's opportunity and possibly the will to make appropriate policy choices (Eifert, Gelb and Tallroth 2003). While Dutch disease is a term used to explain the economic effects, the term "political Dutch disease" has been used to explain the political effects.

Dutch disease theory assumes that the boom-period may be harmful to the oil economy, while the bust-period is relatively harmless. In terms of political stability, however, the bust-period could be critical. The oil dependence generated during the boom-period is crucial to understanding how the bustperiod might affect political stability. If governments are unable or unwilling to dampen the causes of rising resource dependence, the bust-periods will hit 
especially hard for two reasons. First, the failure to diversify away from the oil sector will enhance the effect of the bust due to the lack of a continuous and alternative source of revenue to alleviate the pressure on oil rents. In the long run, this will also inhibit economic growth and social development. Second, because government spending is found to be so closely related to resource rents in oil dependent states (Brahmbhatt and Canuto 2010, Eifert, Gelb and Tallroth 2003), the economy and the population will be extremely vulnerable to both negative and positive economic shocks. The price volatility of oil itself will have a negative influence on investment, economic growth, income distribution and poverty alleviation, and the oil dependent country's vulnerability to this volatility will enhance such effects (Brahmbhatt and Canuto 2010, Gary and Karl 2003).

Resource rents make dependent states prone to economic mismanagement and excessive public spending in boom-periods (Auty 2000, Devlin and Lewin 2005, Lane and Tornell 1996). During boom-periods, the government typically increases expenditures through public sector employment, wage increases, generous unemployment benefits, lower taxes, food subsidies and spending on education and healthcare programs (Basedau and Lay 2009, Eifert et al 2002). Expenditure levels are allowed to rise because governments tend to regard boom-periods as permanent and bust-periods as transitory (Devlin and Lewin 2005). Furthermore, when foreign borrowing occurs it often happens during the boom-period because resources are used as collateral (Ross 2012). This exuberance is also manifested as heightened expectations of better welfare among the population, which invariably shatters during bust periods (Ross 1999). Future expenditure commitments are also established during boomperiods, limiting the government's ability to adjust fiscal policy when oil prices and revenue fall (Devlin and Lewin 2005).

The government's heavy spending and intervention in the economy therefore becomes problematic when resource revenues decline and the expenditure levels are unsustainable (Devlin and Lewin 2005). In states that are dependent upon oil, government expenditure is likely to be determined by current revenue because alternate sources of income are lacking, particularly in heavily oil-dependent countries. When oil prices and revenues are volatile, then, fiscal policy and government (welfare) spending will be volatile, as will aggregate demand and the supply of welfare services (Devlin and Lewin 2005). Borrowing countries will have to repay their debt with interest, causing further discrepancy between disposable income and expenditure commitments (Manzano and Rigobon 2001). These fluctuations thus create spill-over effects throughout the whole economy. In addition to the cuts in welfare spending (health care, education, labor market benefits), low price periods have been associated with decreased real GDP, lower income and higher unemployment rates in oil- 
exporting countries (Cantore, Antimiani and Anciaes 2012). Oil revenue in an oildependent country, thus, determines a society's welfare directly.

Unless strict fiscal rules and spending policies are in place to counter spending volatility and dependence, negative oil price shocks can create ripple effects throughout the economy. The government is forced to reduce spending during bust-periods, causing the population to experience a negative shift in economic welfare caused by contractive policies, a setback of income levels, higher unemployment rates, cuts in direct subsidies, and welfare spending (Brahmbhatt et al. 2010, Gary and Karl 2003). In oil-dependent, heavily government-dominated economies, therefore, people have a point source to direct their frustrations at. More importantly, many oil states are autocracies that need to have access to revenues with which to buy off opposition and keep key supporters happy (Bueno de Mesquita and Smith 2011, Karl 1997, Mahdavy 1970). In addition to economic Dutch disease, oil-rich states suffer political Dutch disease, which is the weak development of a state's bureaucracy and administrative capacity (Fearon 2005). Since oil revenues can replace the need to collect taxes from society as in a more normal setting, oil-rich states rest on a weak administrative edifice. Weak bureaucracies do not provide avenues for addressing social grievances, making it more likely that social dissent spills over into the streets. Figure 1, which plots the price of oil against anti-government protest among oil-producing states is illustrative.

\section{$* * * * *$ FIGURE 1 ABOUT HERE*****}

As demonstrated above, there seems to be a fairly tight correspondence between low-price years and increased anti-government protest. Naturally, while these bivariate relationships provide some basis for discussion, they are clearly insufficient for drawing stronger conclusions about price shocks and political instability.

\subsection{Oil importers}

The reverse of what we discussed might be true in oil-importing countries. Because oil is so widely used in production and transportation and because petroleum products are so widely purchased, a high oil price is thought to have ripple effects throughout the entire economy of an importing country. Oil is a key input for several manufacturers, and as such a high oil price makes production more costly, thereby decreasing aggregate output (Doğrul and Soytas 2010). Periods in which oil prices are high are associated with lower growth rates, declining productivity, rising unemployment and higher inflation in oilimporting countries (see for example Doğrul and Soytas 2010, Hamilton 2000, 
Cantore, Antimiani and Anciaes 2012). This is often explained by classic economic supply theory. As the price of an input good goes up, aggregate output and productivity decline. The reduction in output and productivity thus reduces real GDP and causes inflation. The impact of an oil price spike on economic growth has further consequences for employment levels. As marginal cost rises and productivity falls, unemployment rises (Doğrul and Soytas 2002). In the long run, these effects can be offset by the reallocation of labor and may change the entire production structure. In the short run, however, the economy is incapable of absorbing the excess labor, causing unemployment. One would think that because an increase in the price of oil affects the importing economy negatively, a price decline would constitute an equivalent positive effect. However, the effect of an oil price shock on economic growth is asymmetric. While oil price spikes have empirically been shown to have a negative effect on the importing economy, the magnitude of a price drop is smaller, if it exists at all (Hamilton 2000, Jiménez-Rodríguez and Sanchez 2005).

Consumers are exposed to volatility because oil is relevant for the production, consumption and transportation of a host of other goods. Price levels of durable goods, heating, and food, for example are heavily dependent on the oil price (Hamilton 2000). These price changes are more easily transmitted for oil-based products than most other raw materials, reducing consumer demand in oil importing states (Regnier 2007). Oil-based goods, taken together, make up a very large portion of the basket of goods that producers and consumers purchase in any economy, meaning that the impact of an oil price shock will be far-reaching (Regnier 2007). Important in this regard is perhaps transportation costs of vital non-durable goods such as food. This will cause food prices to increase, affecting the poorer parts of the population, particularly in urban areas that depend on food transported from rural areas.

Additionally, oil price fluctuations will affect the terms of trade by changing the ratio between the value of imports and exports (Cantore, Antimiani and Anciaes 2012). This has implications for the state's balance of payments. The following contraction of the economy to restore equilibrium after an oil price spike will have further effect on GDP and economic growth (Hamilton 2000). At the same time, an increase in the price of oil will increase purchasing power and consumer demand in oil exporting states. Through trade between importers and exporters, the adverse economic effects of a price shock on oil importing states may be restrained. Rasmussen and Roitman (2011) find that an increase in the price of oil is associated with increases in imports and exports in both importing and exporting states. This reflects what they call the recycling of petroleumdollars, indicating that through increased imports, remittances and investments, dollars flow from oil exporting states back to oil importing states (Rasmussen and 
Roitman 2011). Historically, however, this effect has not been enough to offset the development in oil importing states because the increase in demand in oilexporting countries have been smaller than the reduction in demand in oil importing states (Brown, Yucel and Thompson 2003).

The association between oil prices and food prices may be the most important, seeing as an oil price change often constitutes a change in the costs of goods necessary for survival. Because fuel prices are so transmittable, the consequences of volatility are far-reaching in nature, affecting producers and consumers alike. Typically, price hikes are thought to be the main reason people get on the streets, as seen recently in Iran. Oil exporting and oil-importing countries both subsidize petroleum product prices through implicit as well as explicit policies, precisely because they fear dissent (Baig et al. 2007). Both types of states keep reserves, although it is costly to simply store supplies indefinitely. These facts alone indicate that governments do seem to understand the political costs of oil price shocks and prepare for them. Yet, inventories are not sufficient to offset the rigidity of demand and supply, and oil subsidies have been criticized for being inefficient and poorly targeted (Baig et al. 2007, Smith 2009). Try as they may, governments may not be capable of sufficiently countering the effects of a negative oil price shock, but they could lessen the pain of volatility by intervening financially. Figure 2 plots the oil price and anti-government protest among oil importing states.

\section{$* * * * *$ FIGURE 2 ABOUT HERE*****}

As can be seen above, again, there seems to be a fairly tight association between high price periods and increased anti-government protest. Again, despite this bivariate association, only multivariate examination can tell us the true strength of this association and whether or not we might be able to conclude that it is causal.

\subsection{Political Prudence}

Whatever the nature of states and the nature of economic shocks to society, people suffer collective action problems when it comes to challenging the power of incumbent rulers (Olson 1965, Skocpol 1979). Whether a government is a democracy or a repressive autocracy, various forms of political activity and contentious politics exist, sometimes spilling into the streets and at other times not (Kuran 1995, Tilly 2006). Consider that a strict autocracy, such as China has many protests and riots, whereas a fairly weak and incompetent state, such as Sudan, which is far less autocratic than China, suffers fewer protests, even if it contains armed insurgency. Long established democracies, such as India, also 
suffer many forms of contentious political movements, and strikes, riots, and protests are in many states a legalized, institutionalized form of political activity that allows ordinary people to air grievances against the incumbent regime. How incumbent regimes act in such cases might be critical for determining whether or not a non-violent movement becomes violent.

Prudent governments, whether dictatorships or democracies, oil exporters or oil import dependent states, adopt countervailing policies to cauterize potential anti-government threats. Indeed, harmful economic policies, such as food and gasoline price controls, exist because they are good politics (Bates 1988, Bueno de Mesquita and Root 2000, Lipton 1976). Prudent governments, thus, might save for a rainy day by building up foreign exchange reserves and other policy-based strategies. In fact, several IMF reports suggest that oil exporters like Norway, Russia, Saudi Arabia, United Arab Emirates, Qatar, Kuwait, among others are shielded from economic and political uncertainties in the wake of low oil prices because they draw on their FOREX reserves and sovereign wealth funds to finance the public goods and services, fiscal and other investment requirements for easing the pain of a crisis (Arezki, Mzarei and Prasad 2015, Husain et al. 2015). Less prudent governments, such as Hugo Chavez' Venezuela, followed populistic, expansionary policies, essentially squandering the savings from high oil rents, so that the current crisis of austerity has spilled over into the streets. Krugman (2016) argues that in such countries there is a non-linear relationship between oil prices and domestic spending on public goods and services (Krugman 2016). Meaning, when oil prices decline, domestic spending too falls sharply resulting in political unrest, and according to some, may even lead to civil war among oil-producing states (Bodea, Higashijima and Singh 2016).

\section{Data and Methods}

We use panel data for 165 countries between 1980 and 2013 (34 years). ${ }^{5}$ Since some of the data are not available for all countries for all years, our dataset is unbalanced. Our dependent variable, anti-government protest, is a mixture of a number of violent and non-violent protests registered for country $\boldsymbol{i}$ in year $\boldsymbol{t}$. We use the data set developed by Arthur Banks' (2015) Cross-National Times Series (CNTS) Data Archive, which allowed us to create a variable for anti-government protests capturing riots - counts the number clashes with 100 participants involving the use of physical force; anti-government demonstrations - counts public gathering of at least 100 people voicing opposition to government policies (excluding foreign policy issues); and revolutions - counting the number of

\footnotetext{
${ }^{5}$ See Appendix 1 for list of countries.
} 
attempts by demonstrators to change the government. As far as we are aware, Arthur Banks' (2015) data is one of the most widely used data for capturing antigovernment protest directed against a government (Bank, Richter and Sunik 2013, Burke 2012, Collier and Rohner 2008, Dreher and Gassebner 2012). ${ }^{6}$ The descriptive statistics show that there are 1.26 anti-government protests on average covering the 165 countries during our study period with a deviation of 3.88 protests per country. The largest number of protests occurred in Syria in 2011 (82), while Yemen registered about 79 such protests in the same year. The dependent variable - anti-government protests is a count measure, which is strongly skewed to the right (with an accumulation of observations at zero) and displays over dispersion, with the variance being greater than the mean. Thus, the appropriate econometric technique to cope with such data is negative binomial regression (Cameron and Trivedi 2013, Lawless 1987). Note that the 'goodness-of-fit' test, which is reported in our Tables, supports the use of negative binomial over the Poisson estimation method.

The model we estimate might be denoted by the following equations. Let the expected value and the variance be given by:

$$
\begin{aligned}
& E\left(y_{i t}\right)=e^{\left(\alpha_{i}+\beta^{\prime} X_{i t}\right)}=\lambda_{i t} \\
& \operatorname{Var}\left(y_{i t}\right)=\lambda_{i t}\left(1+\delta_{i}\right)
\end{aligned}
$$

Wherein, $y_{i t}$ is the count of the non-violent protests in country $i$ in year $t, \alpha_{i}$ are the country-specific effects and $X_{i t}$ is the vector of explanatory variables. The dispersion (i.e., variance divided by the mean) is given by $1+\delta_{i}$ and is constant over time for each country. We employ country-specific fixed effects to capture time invariant factors that remain constant across countries. Likewise, to account for common shocks, we include year-specific fixed effects and heteroscedasticitly consistent, robust standard errors (Beck and Katz 1996). Note that the Hausman test favors negative binomial with fixed effects over pooled negative binomial regressions.

\footnotetext{
${ }^{6}$ The only alternative dataset on protests and political unrest is the Nonviolent and Violent Campaigns and Outcomes (NAVCO) v. 2.0 data developed by Chenoweth and Stephan (2011). These data are collected on major nonviolent and violent resistance campaigns across the world. The major disadvantage of NAVCO 2.0 is that the data are available only until 2005 and only cover major non-violent upheavals. We want to capture both violent and non-violent protests because any kind of protest signals people's displeasure with the government. How minor protest becomes a major movement, of course, is highly dependent on a stet's response. For this reason, we stay with the CNTS data as many others have done.
} 
We employ three different measures of oil wealth. First, we use oil rents per GDP obtained from the World Development Indicators (WDI hereafter) online dataset (World Bank 2016). ${ }^{7}$ Rents are defined as unit price minus the cost of production times the quantity produced. The World Bank's rents data show that oil rents dominate a country's GDP compared with rents from other natural sources. In our sample of 165 countries, the average oil rents to GDP are $6.1 \%$ with a maximum of $80.3 \%$. Secondly, following previous studies, we use oil exports as a share of total exports (Collier and Hoeffler 2004). The average oil exports to total exports is $18.5 \%$ with a maximum of $100 \%$ registered for Libya in 1980. The bivariate correlation between these two variables is $r=0.84$, suggesting that fuel export dependence and oil rents per GDP measure the value of oil to an economy fairly consistently. Thirdly, it is argued by some that usage of the oil rents variable is problematic because low oil rents could be the result of a low oil price. We use a measure of oil production per GDP which is obtained by disaggregating the oil rents variable into oil production and price parts developed by Ross (2012) and Haber and Mehaldo (2012). This variable has much wider coverage than the World Bank's oil rents and exports variables. The bivariate correlation between oil production and oil rents, oil exports measure is $r=0.78$ and 0.74 respectively.

The vector of control variables includes potential determinants of antigovernment protests gleaned from the existing literature that explains the effect of oil resources (Bodea, Higashijima and Singh 2016, Dreher and Gassebner 2012, Goldstone et al. 2010, van Weezel 2016). We avoid the "garbage can" or "kitchen-sink models" approach and limit our control variables (Achen 2005, Schrodt 2014). We follow the conservative strategy of accounting only for known factors that may confound the effect of resources. First, we include per capita GDP (logged) in US\$ 2005 constant prices obtained from the WDI as a measure of the level of economic development. Income per capita is a 'catch all' variable for factors, such as the quality of institutions and the individual opportunity costs associated with rebellion. We expect economic development to be negatively correlated with anti-government protests (Goldstone et al. 2010). Next, we control for regime type. The lack of democracy fuels protests against governments when people keen for greater political voice and freedom of speech are politically repressed. Conversely, democracy allows freedoms that among other things may encourage protest. We include a measure of democracy

\footnotetext{
${ }^{7}$ These data are accessed from the World Development Indicators online data on August 2016. For a detailed explanation of methodologies and the calculation of rents, see: http://databank.worldbank.org/data/.
} 
using the Marshall and Jaggers (2002) Polity IV index, ${ }^{8}$ which is recoded as a discrete variable taking the value 1 if the Polity index is above +6 (on the -10 to +10 scale), and 0 otherwise. ${ }^{9}$ Likewise, we create a discrete measure of strict autocracy, which takes the value of 1 if the Polity index is below -5 and 0 otherwise because high political repression can dampen open anti-government activity.

We control for economic crises independently of oil price shocks by including a dummy variable experiencing any one of these three crises: currency, debt, and systematic banking crises (Laeven and Valencia 2013). As discussed above, economic crises prompt anti-government protest, but we include these separately to examine the independent effect of oil prices, net of any other crisis a country faces. Following others, we include a measure of trade openness using total trade as a share of GDP (Bussmann, Scheuthle and Schneider 2005, Hegre, Gissinger and Gleditsch 2003). While Hegre et al. (2003) find that trade promotes political stability in the long run, Rogowski (1989) using two classical models of international trade theories - the Ricardo-Viner model and the Stolper-Samuelson model, argues that trade may lead to political instability in the short-run (Bussmann, Scheuthle and Schneider 2005, Rogowski 1987). We include the size of the population since countries with large populations are more difficult to control and large countries are likely to have large resources (van Weezel 2016). Finally, we test the effect of oil dependence on antigovernment protests holding constant ongoing violent armed conflict defined as a war between a state and a rebel group where at least 25 deaths have occurred in a single year (Gleditsch et al. 2002). These data are taken from the website of the Uppsala Conflict data program (UCDP). ${ }^{10}$ The descriptive statistics on all variables are reported in Appendix 2, and details on definitions and data sources are provided in Appendix 3.

\subsection{Endogeneity}

Our oil-dependence measures could be plagued by endogeneity problems if dependence on rents, for example, was caused by other factors also explaining outcomes, such as growth, conflict, or some other unmeasured factor. Moreover, the denominators, GDP and total exports, might also be affected independently by unmeasured factors. Failing to account for endogeneity, thus, might yield biased results. To deal with this issue we follow Meyersson, Padro i-

\footnotetext{
8 The Polity index captures three important elements of democracy namely, presence of institutions, existence of effective constraints on the executive and wide participation in the political process.

${ }_{9}^{9}$ Note that estimating the models simply using the full Polity index does not alter our basic results.

${ }^{10}$ The data can be downloaded at: http://ucdp.uu.se/
} 
Miquel and Qian (2008) who use two instrumental variables affecting oil wealth. First, we use total world consumption per capita minus the consumption per capita of $i^{\text {th }}$ country in question (logged). These data are taken from the WDI. Secondly, we use total world consumption of petroleum minus the petroleum consumption of $i^{\text {th }}$ country in question (logged) measured in barrels per day sourced from the Energy Information Administration (EIA, hereafter). As demand for oil in the world increases, countries producing oil will increase their exports to the rest of the world more than those countries who do not produce oil. In all likelihood, this increase in oil exports to rest of the world (and thereby increase in oil rents) as a result of an increase in demand for oil will be orthogonal to political unrest in that country. These two measures of consumption drive the demand for oil and hence are more likely to be exogenous to the dependent variable - political unrest in country $i$. We estimate instrumental variable techniques to ensure that our results are not biased by reverse causality and omitted variables.

The validity of the instrument depends on two conditions. The first is instrument relevance, which is that the instruments must be correlated with the explanatory variable in question - otherwise it has no power. Bound, Jaeger and Baker (1995) suggest examining the F-statistic on the excluded instruments in the first-stage regression. The selected instrument would be relevant when the first stage regression model's F-statistics is above 10 (Bound, Jaeger and Baker 1995). We estimate the first step regressions to assess the relevance of the instruments. The results are reported in an online appendix. Secondly, the selected instruments should not vary systematically with the disturbance term in the second stage equation, i.e. $\left[\omega_{i t} \mid I V_{i t}\right]=0$. This means that the instrument cannot directly determine the outcome variable. We test for instrument exclusion criteria by regressing anti-government protests on both instruments and including all the control variables. We also control for time and country specific dummies. We find no evidence that an increase in general consumption and petroleum consumption in the rest of the world causes an increase in protest in country $i$. These results are reported in the online appendix. With these tests, we are confident in avoiding the weak instrument problem.

\subsection{Two-way Interaction effects - The oil price effect}

Our main hypothesis is that significant decrease in the oil price is associated with anti-government protest in oil-exporting states. We expect the reverse in oilimporting states. Additionally, anti-government protest should be worse in countries that lack forex reserves. We use historical oil price data adjusted for inflation sourced from the US department of the EIA. ${ }^{11}$ Using the historic oil price

${ }^{11}$ Oil price data are available here: http://www.eia.gov (last accessed January 2017). 
data we create low and high oil price years employing discrete variables. The low oil price period takes the value 1 for those years for which the oil price over the 1980-2013 period is below the median value and 0 if not. A high oil price period takes the value 1 for those years for which the oil price over the 1980-2013 period is above the median, and 0 if not. We do this to investigate whether oil resource-dependent countries are more (or less) likely to suffer protests when oil prices are lower (or higher), independent of all the controls in the model. Next, we do the same analyses using the oil price periods and their interactions with oil importing states, measured as oil-imports-to-GDP taken from the WDI. Once again, we employ the negative binomial estimator controlling for country and time-specific fixed effects.

\subsection{Three-way Interaction effects - The Forex Reserves effect}

In the final step, we examine if some oil-wealthy states are able to stave off antigovernment protest during lean price years because of their access to foreign exchange reserves. In order to test this proposition, we introduce a three-way interaction effect in which we interact the low oil price period dummy with our oil wealth measures and access to forex reserves. We use the data on total accumulated foreign exchange reserves measured in US\$ millions current prices as a share of GDP taken from the WDI. The mean value of reserves is about $13.3 \%$ of GDP per country with a minimum value of zero and a maximum value of $302 \%$ of GDP. It is noteworthy that there is some variation in the data distribution. For instance, $99 \%$ of the forex reserves data are less than $110 \%$ of GDP, and the majority of cases fall between 0 and $100 \%$. We thus use two different operationalization of forex reserves variables: (1) We log the forex reserves /GDP to address the problem of skew; (2) We exclude data points above $110 \%$ of GDP, which is roughly less than $1 \%$ of the total data. ${ }^{12}$ To interpret the three-way interaction results, we rely on marginal plots where we examine the impact of low oil price at various levels of oil rents/GDP, oil exports/total exports, oil production/GDP and forex reserves/GDP (logged) on anti-government protest. Similarly, we also introduce one more three-way interaction specification in which we examine the impact of high oil prices on protest in oil-importing countries (measured as oil imports/total imports) at various levels of forex reserve/GDP (logged). It is true that the ability of the ruler to increase expenditures to assuage demand for public goods when oil prices change dramatically might necessitate deficit spending and increase debt, especially in oil-dependent states. But, we argue that those oil-importing countries that accumulate large cash reserves can mitigate the effects of oil price shocks more

12 These results are reported in an online appendix as a part of all robustness checks. 
easily than by borrowing, which might still require measures of austerity to ensure debt pay-back. Again, we employ the negative binomial estimator to estimate three-way interactions controlling for country and time-specific fixed effects.

\section{Results}

Table 1 reports the impact of oil wealth on anti-government protests. While columns 1-3 present the results of oil rents as a share of GDP, oil exports as a share of total exports and oil-production-to-GDP. Note that the results in columns 4-6 are estimated using the IV Poisson estimator to address endogeneity concerns.

\section{$* * * *$ TABLE 1 ABOUT HERE $* * * *$}

As seen in column 1-3, all three measures of oil wealth are positive and statistically insignificant on anti-government protests. These results remain statistically non-significant when additional controls - economic crises, population, trade, and civil conflict - are added. As expected, economic crisis, independent of resource wealth, increases protests, as does an ongoing armed conflict between a government and a rebel group(s). Strong democracy seems robustly related to lower anti-government protests while strong autocracy has a marginal statistical divergence from zero. The results of the control variables are in line with the findings of others (Bohlken and Sergenti 2010, Gupte, Justino and Tranchant 2014, Robertson and Teitelbaum 2011). Interestingly, per-capita income is not statistically significant in most of the models, which suggests that insofar as per-capita income captures state capacity and wealth, people are no less or more likely to protest than places which are economically poorer. Notice that oil rents and oil exports results remain statistically insignificant when estimating the IV model in column 4-5, suggesting that alternative measures of oil wealth make no difference. However, the oil production variable is positive and statistically significant at the $5 \%$ level. These results taken together suggest a positive but statistically unrobust direct effect of having oil wealth on the risk of anti-government protest.

\section{$* * * * *$ TABLE 2 ABOUT HERE $* * * * *$}

In Table 2, we examine the conditional effects between oil wealth and low oil price periods on anti-government protest. In columns 1-3, we report the interaction effects between our three measures of oil wealth and the low oil price dummy. As seen from all three columns, the conditional effect of oil wealth 
and low prices increases protest, results which are now statistically highly significant. Interestingly, the low-price period when oil wealth is zero shows highly significant negative effects. This result already hints at the beneficial effects of low oil prices for political stability provided oil wealth is not a significant share of a country's income. The results taken together suggest that countries dependent on oil experience political unrest conditional on low oil prices, while non-producers enjoy stability.

For easy interpretation of the results, we compute the incidence-rate ratios (IRR, hereafter). The IRR computes a one unit change in the corresponding variable (i.e. oil rents to GDP conditional upon low oil price) on the expected change in the number of protest events (IRR of coefficient-1) $\times 100$ percent. An IRR of a variable above 1 indicates a positive association with political unrest while the reverse is true for values below 1 . The lower-bound of the IRR is zero, which suggests that the expected variation in the dependent variable is zero for one unit increase in variable $X$ (i.e., a change by -100 percent). For example, in column 1 where we include all the relevant controls, at the mean of oil rents to GDP (which is roughly 6.0\%) there is an expected increase in the number of protests by only $2 \%$ under low oil price conditions. However, a standard deviation increase in oil rents to GDP (about 12.63\%) above the mean, holding other controls constant at their mean values, increases the expected number of anti-government protests by $18 \%$ conditional on low oil prices. Substantively, the effects are large. For example, consider a country enjoying the maximum of oilrents-to-GDP (which is $80.24 \%$ in our sample), then the expected increase in protests during low oil price periods would increase by over $173 \%$. Very similar substantive effects also hold for oil export share and oil production to GDP. Again, the results on the control variables remain much the same and in line with the findings of others. These results support the view that price shocks have significant effects on oil producers, but only when oil prices are low.

\section{$* * * * *$ TABLE 3 ABOUT HERE}

Next, we turn to oil import dependent countries and anti-government protest. Columns 1 report results on the direct effect of being dependent on importing oil and the incidence of anti-government protest. As seen there, greater import dependence on fuel is associated with higher protest, but as column 2 show, the positive effects of oil import dependence are driven entirely by high price conditions. Contrarily, results in column 3 suggest that countries that are dependent on imports suffer lower anti-government protests than others when prices are low, results which are significantly different from zero at the $1 \%$ level. Substantively, a standard deviation increase in oil imports to total 
imports above the mean, holding other controls constant at their mean values, increases the expected number of anti-government protest by $33 \%$ when oil prices are high. But, increasing the oil imports by the maximum value (i.e., $64.14 \%$ of total imports) would increase the anti-government protest by $312 \%$ when oil prices are high. Notice that the high oil price dummy on its own would increase the expected number of anti-government protest by over $78 \%$, which is significantly different from zero at the $1 \%$ level (see column 2 ). The results taken together suggest that oil-import dependent countries are vulnerable to increases in the price of oil.

\section{$* * * * *$ TABLE 4 ABOUT HERE $* * * * *$}

Next, we examine whether the decline in anti-government protest in oil wealthy states during low oil price periods is conditional upon the degree of political prudence measured by the accumulation of forex reserves. Accordingly, we introduce three-way interaction term between the low oil price dummy, oil rents/GDP, and forex reserves/GDP ( $\log$ ) in column 1 . In columns 2 and 3, we replace oil rents with the share of oil exports and oil production to GDP. In column 1 , the conditional effect between low oil price, oil rents and forex reserves is negative on anti-government protest, a result which supports our hypothesis that some oil-wealthy countries stave off protests when oil prices are low which is conditional on access to adequate forex reserves. Importantly, low oil prices on its own, i.e., when the value of oil rents and forex reserves are set to 0 , has a stronger negative effect on anti-government protest, which is significantly different from zero at the $1 \%$ level (see column 1 ). Also, the two-way interaction between oil rents and low oil prices, i.e., when forex reserves are set to 0 , has a positive and statistically significant effect on protest. These effects suggest clearly that in the absence of forex reserves, low oil prices are associated with anti-government protest. The results uphold in columns 2 and 3 when we replace oil rents with fuel export share and oil production share.

The three-way interactive effects are best assessed with margins plots presented in Figure 3-5 respectively. It is important to note that the interpretation of the interaction term in non-linear models like the negative binomial is not similar to interpreting linear models. Consequently, a simple ttest on the coefficient of the interaction term is not sufficient to examine whether the interaction is statistically significant (Ai and Norton 2003). We rely on marginal plots as shown in Figure 3, which depict the magnitude of the interaction effects. 
To calculate the marginal effect of low oil price at different levels of oil rents/GDP, we consider both the conditioning variable (i.e., forex reserves/GDP logged) and the three-way interaction term, displaying graphically the total marginal effect conditional on oil rents/GDP and forex reserves/GDP (log). The yaxis of Figure 3 displays the marginal effect of low oil price period, and the marginal effect is evaluated on the forex reserves/GDP (log) on the $x$-axis at various levels of oil rents/GDP namely, at $0 \%, 20 \%, 40 \%, 60 \%$ and $80 \%$ respectively. Note that we include the $90 \%$ confidence interval in the figure. As seen in Figure 3, and in line with our results of the negative binomial estimations, low oil prices decrease the expected number of protest (at the $90 \%$ confidence level) for countries with oil rents of $20 \%$ of GDP conditional on forex reserves (logged) being higher than 2 (on a scale of -6 to +6 ), which is about $8 \%$ of reserves to GDP. For instance, the substantive effects show that when oil prices are low, a country with $20 \%$ of oil rents/GDP accumulating forex reserves by $8 \%$ of GDP would see a decline in the expected number of anti-government protest by $42 \%$. We also see that the expected number of protest would decline by $69 \%$ if countries with $40 \%$ oil rents/GDP accumulate forex reserves of roughly $55 \%$ of GDP. Finally, in the case of countries with oil rents worth $80 \%$ of GDP, the expected number of protests decline by $93 \%$ if forex reserves are roughly $300 \%$ of GDP, which is significantly different from zero at the $1 \%$ level. ${ }^{13}$ However, what is striking is if oil wealthy countries (with $80 \%$ of oil rents to GDP) with no forex reserves would increase the expected number of anti-government protest by as much as $420 \%$ during low oil price period. It is noteworthy that the interaction effects are similar when estimating the three-way interactions with oil-export-share- and oil-production-share-to-GDP.

\section{$* * * * *$ TABLE 5 ABOUT HERE***}

Next, we examine the three-way interactions on our oil import dependent-states (Table 5). If oil-importing countries are vulnerable to high oil prices (as seen in Table 3), are some of these states able to reduce their vulnerability to anti-government protest if they have healthy forex reserves? As seen in column, the three-way interaction term is negative but is statistically insignificant. However, we know that a simple t-test on the coefficient of the

\footnotetext{
${ }^{13}$ Our results on three-way interactions remain robust to using the alternative data on forex reserves/GDP $(\log )$ wherein we elimiate the ouliers. These results are reported in online appendix.
} 
interaction term is not sufficient. Thus, we display the relationship in marginal plot as shown in Figure 6, which depicts the magnitude of the three-way interaction effect.

$* * * * *$ FIGURE 6 ABOUT HERE****

The $y$-axis of Figure 6 displays the marginal effect of the high oil price scenario, and the marginal effect is evaluated on forex reserves/GDP (logged) on the $x$-axis at various levels of oil import dependence; namely at $0 \%, 13 \%, 26 \%, 39 \%, 52 \%$ and $65 \%$ respectively. As can be seen, high oil prices would actually decrease the expected number of protests (at the $90 \%$ confidence level at least) for oilimporting countries as they accumulate forex reserves. For instance, high oil prices increase the expected number of protests by $280 \%$ among countries that are oil import dependent at 39\% of total imports if their forex reserves are at 0. However, the expected number of protest could reduce by $130 \%$ if forex reserves are about $300 \%$ of GDP. It is noteworthy that these results are not robust as the marginal effect of high oil prices is insignificant at the higher end of forexreserves-to-GDP (logged) in the category of oil imports of $52 \%$ and $65 \%$ of total imports. However, the two-way interaction between oil imports and the high oil price period dummy is positive and significantly different from zero, which corroborates our earlier findings reported in Table 3. Notice also that the individual effect of high oil prices, that is when the values of oil imports and forex reserves are set to 0 , is positive and statistically significant at the $5 \%$ level. Overall, our three-way interactions show that while oil prices do have political effects in both producer and import-dependent countries, prudent governance that ensures adequate forex reserves can alleviate the negative political effects of austerity.

\subsection{Robustness checks}

We subject our main findings to a barrage of robustness checks. First, following Vadlamannati and de Soysa (2018) and Bodea et al. (2016), we estimate all our models by excluding outliers in our oil rents and oil exports variables that have more than $75 \%$ oil rents as a share of GDP, $90 \%$ oil exports as a share of total exports and $40 \%$ oil production to GDP. Excluding the outliers from the sample does not change our main results. These results are reported in the online appendix. Our results from the restricted sample shows that both oil wealthy and oil-consuming states are sensitive to fluctuations in oil prices, and that forex reserves can condition price effects on protest. This suggests that our results are not driven by outliers in the oil variables. Second, we use a new definition to create low and high oil price dummies. Accordingly, the low oil price dummy 
takes the value of 1 for those years for which the oil price over 1980-2013 period was below one standard deviation of the mean value, which is about 76 US\$ and 0 otherwise. Similarly, high oil price scenario takes the value of 1 for those years for which the oil price over 1980-2013 period was one standard deviation above the mean value and 0 otherwise. Estimating our models with these new oil price measures does not drastically change our results. ${ }^{14}$ All three-way interaction effects are upheld. Third, we exclude high-income Western democracies from our sample ${ }^{15}$ as some of the high-income countries like Australia, Canada and Norway are highly democratic with relatively low levels of corruption. Furthermore, most of the high-income countries are also net-importers of oil, but oil consumption is only a relatively small part of their GDP. The exclusion of this group of countries from our sample makes little difference to the basic results reported above.

Fourth, we are concious of not overfitting our regression models. To address this problem we adopt two appraoches. First, we drop all controls which are statistically insignificant in all our models, retaining only those controls which are significant at conventional levels. Second, we restimate all our models dropping one control variable at a time. ${ }^{16}$ The basic results are not affected when we drop the variables which are statistically insignificant. Fifth, our baseline models do not account for temporal dynamics of political unrest. To account for this, we drop country fixed effects and include the temporal lag of the outcome variable as a robustness check. We find our results to remain firmly robust to the inclusion of a temporal lag variable.

Finally, following Brandt et al. (2000), we replicate the baseline results reported in Tables 1-4 using the zero-inflated negative binomial method. Although it is true that there is overdispersion in the protests data, it provides a good test for the robustness of our findings as an alternative estimation technique. Our results are virtually unchanged. Additionally, we tease out potential causal mechanisms by estimating a three-way interaction between low price of oil, oil rents, and final government consumption ${ }^{17}$ per capita (logged) sourced from the WDI. Our results suggest that when oil prices are low, countries which are dependent on oil wealth would see a decline in anti-government

\footnotetext{
${ }^{14}$ The two-way interaction results reported in Table 2-3 are statistically insignificant when using the new measure of low and high oil price dummies.

15 These include: Australia, Austria, Belgium, Canada, Denmark, France, Finland, Germany, Ireland, Italy, Netherlands, New Zealand, Norway, Portugal, Spain, Sweden, Switzerland, United Kingdom, and United States.

${ }^{16}$ Note that we also use Area Under Curve (AUC) to gauge the predictive power of the variables in the models by dropping one variable at a time to analyze the effect on the model's fit. We find most of our variables have good predictive power.

${ }^{17}$ We use government consumption data here because the data on government expenditure is not fully available for all 165 countries over 34 years.
} 
protest when government consumption increases. Overall, these findings suggest that our results are robust not only to the size of the sample and alternative methods of operationalization of our main variables of interest (including the oil price), but also to alternative estimation techniques.

\section{Conclusion}

Arguments about the natural resource curse suggest that oil wealth is associated with political unrest and civil wars (Le Billon 2005, Ross 2012). For some, natural resources, such as oil, are lootable assets that make the organization of violence feasible (Collier, Hoeffler and Rohner 2009, Lujala 2010). Others argue that oil wealth emasculates state capacity, making them vulnerable to insurgency (Fearon 2005). Yet again, others argue that oil relates to a complex of "petrocapitalism" that is inherently unstable and resisted by the vast majority of people denied their fair share (Watts 2005). Empirically, however, there is a fairly large bit of variance among oil-producing countries that experience unrest and don't (Bodea, Higashijima and Singh 2016). Recently, petro-capitalist states, such as Saudi Arabia, remained stable while many of her neighbors, such as Egypt, were wracked by anti-government protest. Countries, such as Venezuela, which has a tightly state-controlled petroleum industry seems to have enjoyed stability as long as prices remained high, but today Venezuelans suffer deep austerity, resulting in large anti-government protests and unrest (Cawthorne and Ulmer 2016). Similar incidents have flared up recently in Iran, apparently due to price hikes of essentials, such as food and perceived government corruption. Indeed, many aspects of the resource curse are thought to exist precisely because oil wealth allows rulers to buy off opposition, perpetuating bad policy (Acemoglu and Robinson 2012, Basedau and Lay 2009). What explains this variation?

We argue that the effect of oil wealth on political unrest is conditional upon oil price volatility. More specifically, oil-producing states can be vulnerable to political instability when oil prices are low because of austerity. The same effects hold for oil-consuming states when oil prices are high. The mechanism explaining political unrest, however, is the relative austerity experienced by the general population. However, accumulation of foreign exchange reserves by oilproducing and consuming states can attenuate the effect of oil price volatility. Our arguments are robustly supported in the data. The effects are not just statistically significant, but they are substantively fairly large. Although we find similar results for oil-importing countries when oil prices are high, the results are not as robust for the hypothesized mechanisms as for oil producers. Nevertheless, these results highlight the important role for prudent governance of oil wealth argued by many (Auty and Gelb 2000, Eifert, Gelb and Tallroth 2003, 
Mehlum, Moene and Torvik 2006). The results also support those that suggest that prudent governance in terms of public spending on education may conditionally lower the risk of civil war among oil-producing states (Bodea, Higashijima and Singh 2016). Ultimately, our results support the view that prudent leadership and management of the economy is necessary to avoid political instability in oil-wealthy states vulnerable to shocks. 
Table 1: Impact of oil rents on the non-violent protests (Baseline models)

\begin{tabular}{|c|c|c|c|c|c|c|}
\hline & $\begin{array}{c}\text { (1) } \\
\text { Protests }\end{array}$ & $\begin{array}{c}(2) \\
\text { Protests }\end{array}$ & $\begin{array}{c}(3) \\
\text { Protests }\end{array}$ & $\begin{array}{c}(4) \\
\text { Protests }\end{array}$ & $\begin{array}{c}(5) \\
\text { Protests }\end{array}$ & $\begin{array}{c}\text { (6) } \\
\text { Protests }\end{array}$ \\
\hline Oil Rents/GDP (t-1) & $\begin{array}{l}-0.00860 \\
(0.00667)\end{array}$ & & & $\begin{array}{l}-0.0899 \\
(0.0836)\end{array}$ & & \\
\hline Oil Exports/Total Exports (t-1) & & $\begin{array}{l}-0.00329 \\
(0.00249)\end{array}$ & & & $\begin{array}{l}-0.00358 \\
(0.0573)\end{array}$ & \\
\hline Oil Production/GDP (t-1) & & & $\begin{array}{l}-0.00718 \\
(0.00828)\end{array}$ & & & $\begin{array}{l}0.566^{* *} \\
(0.257)\end{array}$ \\
\hline Per capita GDP $(\log )(\mathrm{t}-1)$ & $\begin{array}{c}-0.0434 \\
(0.141)\end{array}$ & $\begin{array}{c}-0.0345 \\
(0.156)\end{array}$ & $\begin{array}{l}-0.0518 \\
(0.130)\end{array}$ & $\begin{array}{l}-0.326 \\
(0.226)\end{array}$ & $\begin{array}{l}-0.499^{*} \\
(0.265)\end{array}$ & $\begin{array}{c}-0.825^{* * *} \\
(0.276)\end{array}$ \\
\hline Democracy (t-1) & $\begin{array}{c}-0.249^{* * *} \\
(0.0899)\end{array}$ & $\begin{array}{c}-0.338^{* * *} \\
(0.0906)\end{array}$ & $\begin{array}{c}-0.326^{* * *} \\
(0.0848)\end{array}$ & $\begin{array}{c}-0.522^{* * *} \\
(0.149)\end{array}$ & $\begin{array}{c}-0.497^{* * *} \\
(0.183)\end{array}$ & $\begin{array}{c}-0.535^{* * *} \\
(0.173)\end{array}$ \\
\hline Autocracy $(\mathrm{t}-1)$ & $\begin{array}{c}0.0481 \\
(0.0981)\end{array}$ & $\begin{array}{c}0.00917 \\
(0.100)\end{array}$ & $\begin{array}{l}-0.0702 \\
(0.0906)\end{array}$ & $\begin{array}{l}0.265^{*} \\
(0.145)\end{array}$ & $\begin{array}{c}0.248 \\
(0.167)\end{array}$ & $\begin{array}{c}0.234 \\
(0.181)\end{array}$ \\
\hline Economic Crises (t-1) & $\begin{array}{l}0.275^{* * *} \\
(0.0839)\end{array}$ & $\begin{array}{l}0.260^{* * *} \\
(0.0844)\end{array}$ & $\begin{array}{l}0.258^{* * *} \\
(0.0803)\end{array}$ & $\begin{array}{c}0.544^{* * *} \\
(0.160)\end{array}$ & $\begin{array}{c}0.595^{* * *} \\
(0.209)\end{array}$ & $\begin{array}{l}0.408^{* *} \\
(0.161)\end{array}$ \\
\hline Population $(\log )(\mathrm{t}-1)$ & $\begin{array}{c}0.148 \\
(0.288)\end{array}$ & $\begin{array}{c}0.234 \\
(0.296)\end{array}$ & $\begin{array}{l}-0.171 \\
(0.267)\end{array}$ & $\begin{array}{c}0.391 \\
(0.602)\end{array}$ & $\begin{array}{c}0.860 \\
(0.525)\end{array}$ & $\begin{array}{c}4.537^{* * *} \\
(1.459)\end{array}$ \\
\hline Trade/GDP (t-1) & $\begin{array}{c}0.00105 \\
(0.00191)\end{array}$ & $\begin{array}{c}0.00261 \\
(0.00195)\end{array}$ & $\begin{array}{c}0.000387 \\
(0.000783)\end{array}$ & $\begin{array}{l}0.00980 \\
(0.0106)\end{array}$ & $\begin{array}{c}0.00420 \\
(0.00404)\end{array}$ & $\begin{array}{r}-0.000710 \\
(0.00105)\end{array}$ \\
\hline Civil conflict (t-1) & $\begin{array}{l}0.422^{* * *} \\
(0.0813)\end{array}$ & $\begin{array}{l}0.445^{* * *} \\
(0.0840)\end{array}$ & $\begin{array}{l}0.519^{* * *} \\
(0.0756)\end{array}$ & $\begin{array}{c}0.586^{* * *} \\
(0.127)\end{array}$ & $\begin{array}{c}0.547^{* * *} \\
(0.109)\end{array}$ & $\begin{array}{c}1.060^{* * *} \\
(0.149)\end{array}$ \\
\hline Constant & $\begin{array}{l}-2.519 \\
(5.126) \\
\end{array}$ & $\begin{array}{l}-4.050 \\
(5.321) \\
\end{array}$ & $\begin{array}{r}2.887 \\
(4.725) \\
\end{array}$ & $\begin{array}{l}-2.296 \\
(9.772) \\
\end{array}$ & $\begin{array}{l}-8.422 \\
(8.101) \\
\end{array}$ & $\begin{array}{c}-44.19^{* * *} \\
(4.003) \\
\end{array}$ \\
\hline Estimation Technique & NBREG & NBREG & NBREG & IV-poisson & IV-poisson & IV-poisson \\
\hline Pearson goodness-of-fit & $12724^{* * *}$ & $13091^{* * *}$ & $13939^{* * *}$ & -- & --- & -- \\
\hline Hausaman test (p-value) & 0.986 & 0.000 & 0.000 & 0.000 & 0.000 & 0.000 \\
\hline Country Fixed Effects & Yes & Yes & Yes & Yes & Yes & Yes \\
\hline Year Fixed Effects & Yes & Yes & Yes & Yes & Yes & Yes \\
\hline Number of Countries & 127 & 147 & 151 & 127 & 147 & 151 \\
\hline Total Observations & 3,820 & 4,063 & 4,558 & 3,820 & 4,063 & 4,558 \\
\hline
\end{tabular}

\section{Notes:}

(1) Robust standard errors in parenthesis

(2) Statistical significance: ${ }^{* *} p<0.01,{ }^{* *} p<0.05,{ }^{*} p<0.1$

(3) Negative binomial estimator reports coefficients 
Table 2: Oil price effect - Interactions of oil wealth with oil prices

\begin{tabular}{|c|c|c|c|}
\hline & $\begin{array}{c}(1) \\
\text { Protests }\end{array}$ & $\begin{array}{c}(2) \\
\text { Protests }\end{array}$ & $\begin{array}{c}\text { (3) } \\
\text { Protests }\end{array}$ \\
\hline Oil Rents/GDP (t-1) X Low oil prices (t-1) & $\begin{array}{c}0.0118^{* *} \\
(0.00515)\end{array}$ & & \\
\hline Oil Rents/GDP (t-1) & $\begin{array}{l}-0.00929 \\
(0.00675)\end{array}$ & & \\
\hline Oil Exports/Total Exports (t-1) X Low oil prices (t-1) & & $\begin{array}{c}0.00341^{*} \\
(0.00177)\end{array}$ & \\
\hline Oil Exports/Total Exports (t-1) & & $\begin{array}{c}-0.00425^{*} \\
(0.00255)\end{array}$ & \\
\hline Oil Production/GDP (t-1) X Low oil prices ( $\mathrm{t}-1)$ & & & $\begin{array}{c}0.0409 * * * \\
(0.0133)\end{array}$ \\
\hline Oil Production/GDP (t-1) & & & $\begin{array}{c}-0.0497^{* * *} \\
(0.0164)\end{array}$ \\
\hline Low Oil prices $(\mathrm{t}-1)$ & $\begin{array}{c}-0.902^{* * *} \\
(0.182)\end{array}$ & $\begin{array}{c}-0.942^{* * *} \\
(0.183)\end{array}$ & $\begin{array}{c}-0.818^{* * *} \\
(0.172)\end{array}$ \\
\hline Per capita GDP $(\log )(t-1)$ & $\begin{array}{c}0.00812 \\
(0.143)\end{array}$ & $\begin{array}{c}-0.00301 \\
(0.157)\end{array}$ & $\begin{array}{c}-0.0159 \\
(0.130)\end{array}$ \\
\hline Democracy $(\mathrm{t}-1)$ & $\begin{array}{l}-0.258^{* * *} \\
(0.0900)\end{array}$ & $\begin{array}{c}-0.349 * * * \\
(0.0908)\end{array}$ & $\begin{array}{c}-0.316^{* * *} \\
(0.0849)\end{array}$ \\
\hline Autocracy $(\mathrm{t}-1)$ & $\begin{array}{c}0.0262 \\
(0.0981)\end{array}$ & $\begin{array}{r}-0.0115 \\
(0.100)\end{array}$ & $\begin{array}{l}-0.0855 \\
(0.0906)\end{array}$ \\
\hline Economic Crises $(\mathrm{t}-1)$ & $\begin{array}{l}0.267^{* * *} \\
(0.0840)\end{array}$ & $\begin{array}{l}0.253^{* * *} \\
(0.0845)\end{array}$ & $\begin{array}{l}0.251^{* * *} \\
(0.0803)\end{array}$ \\
\hline Population $(\log )(t-1)$ & $\begin{array}{c}0.206 \\
(0.290)\end{array}$ & $\begin{array}{c}0.245 \\
(0.296)\end{array}$ & $\begin{array}{l}-0.118 \\
(0.268)\end{array}$ \\
\hline Trade/GDP (t-1) & $\begin{array}{l}0.000363 \\
(0.00194)\end{array}$ & $\begin{array}{c}0.00243 \\
(0.00194)\end{array}$ & $\begin{array}{c}0.000570 \\
(0.000778)\end{array}$ \\
\hline Civil conflict ( $\mathrm{t}-1)$ & $\begin{array}{l}0.425^{* * *} \\
(0.0813)\end{array}$ & $\begin{array}{l}0.451^{* * *} \\
(0.0840)\end{array}$ & $\begin{array}{l}0.516^{* * *} \\
(0.0754)\end{array}$ \\
\hline Constant & $\begin{array}{l}-3.726 \\
(5.156)\end{array}$ & $\begin{array}{l}-4.378 \\
(5.321)\end{array}$ & $\begin{array}{c}1.764 \\
(4.744)\end{array}$ \\
\hline Estimation Technique & NBREG & NBREG & NBREG \\
\hline Pearson goodness-of-fit & $12324^{* * *}$ & $13091^{* * *}$ & $13885^{* * *}$ \\
\hline Hausaman test & 0.000 & 0.000 & 0.000 \\
\hline Country Fixed Effects & Yes & Yes & Yes \\
\hline Year Fixed Effects & Yes & Yes & Yes \\
\hline Number of Countries & 127 & 147 & 151 \\
\hline Total Observations & 3,820 & 4,063 & 4,558 \\
\hline
\end{tabular}

Notes:

(1) Robust standard errors in parenthesis

(2) Statistical significance: $* * * p<0.01,{ }^{* *} p<0.05,{ }^{*} p<0.1$

(3) Negative binomial estimator reports coefficients 
Table 3: Oil price effect on oil import dependent countries

\begin{tabular}{lccc}
\hline & $\mathbf{( 1 )}$ & $\mathbf{( 2 )}$ & $\mathbf{( 3 )}$ \\
& Protests & Protests & Protests \\
\hline Oil Imports/Total Imports (t-1) X High oil prices (t-1) & & $0.0205^{* * *}$ & \\
& & $(0.00584)$ & \\
High Oil prices (t-1) & \multicolumn{2}{c}{$0.562^{* * *}$} & \\
& & $(0.198)$ & \\
Oil Imports/Total Imports (t-1) X Low oil prices (t-1) & & & $-0.0205^{* * *}$ \\
& & & $(0.00584)$ \\
Low Oil prices (t-1) & & & $-0.562^{* * *}$ \\
& & & $(0.198)$ \\
Oil Imports/Total Imports (t-1) & & & \\
& $0.00874^{* *}$ & -0.00761 & $0.0129^{* * *}$ \\
Per capita GDP (log) (t-1) & $(0.00437)$ & $(0.00650)$ & $(0.00452)$ \\
& -0.125 & -0.140 & -0.140 \\
Democracy (t-1) & $(0.166)$ & $(0.166)$ & $(0.166)$ \\
& $-0.340^{* * *}$ & $-0.343^{* * *}$ & $-0.343^{* * *}$ \\
Autocracy (t-1) & $(0.0928)$ & $(0.0926)$ & $(0.0926)$ \\
& 0.0804 & 0.0699 & 0.0699 \\
Economic Crises (t-1) & $(0.106)$ & $(0.106)$ & $(0.106)$ \\
& $0.271^{* * *}$ & $0.285^{* * *}$ & $0.285^{* * *}$ \\
Population (log) (t-1) & $(0.0868)$ & $(0.0869)$ & $(0.0869)$ \\
& 0.0202 & 0.0495 & 0.0495 \\
Trade/GDP (t-1) & $(0.314)$ & $(0.316)$ & $(0.316)$ \\
Civil conflict (t-1) & $0.00350^{*}$ & 0.00259 & 0.00259 \\
Constant & $(0.00207)$ & $(0.00210)$ & $(0.00210)$ \\
\hline Estimation Technique & $0.455^{* * *}$ & $0.440^{* * *}$ & $0.440^{* * *}$ \\
Pearson goodness-of-fit & $(0.0858)$ & $(0.0858)$ & $(0.0858)$ \\
Hausaman test & -0.471 & -1.391 & -0.829 \\
Country Fixed Effects & $(5.629)$ & $(5.600)$ & $(5.662)$ \\
Year Fixed Effects & NBREG & NBREG & NBREG \\
Number of Countries & $12797^{* * *}$ & $12741^{* * *}$ & $12741^{* * *}$ \\
Notal Observations & 0.999 & 0.000 & 0.000 \\
& Yes & Yes & Yes \\
& Yes & Yes & Yes \\
& 153 & 153 & 153 \\
& & 3,934 & 3,934 \\
\hline & &
\end{tabular}

\section{Notes:}

(1) Robust standard errors in parenthesis

(2) Statistical significance: ${ }^{* *} p<0.01,{ }^{* *} p<0.05,{ }^{*} p<0.1$

(3) Negative binomial estimator reports coefficients 
Table 4: Forex Reserves effect - Interactions of oil wealth, oil prices and Forex reserves

\begin{tabular}{|c|c|c|c|}
\hline & $\begin{array}{c}\text { (1) } \\
\text { Protests }\end{array}$ & $\begin{array}{c}(2) \\
\text { Protests }\end{array}$ & $\begin{array}{c}(3) \\
\text { Protests }\end{array}$ \\
\hline Oil Rents/GDP (t-1) X Low oil prices (t-1) X Forex Reserves/GDP (log) (t-1) & $\begin{array}{c}-0.0141^{* * *} \\
(0.00470)\end{array}$ & & \\
\hline Oil Rents/GDP (t-1) X Low oil prices (t-1) & $\begin{array}{c}0.0481^{* * *} \\
(0.0126)\end{array}$ & & \\
\hline Oil Rents/GDP (t-1) X Forex Reserves/GDP (log) (t-1) & $\begin{array}{l}0.0142^{* * *} \\
(0.00352)\end{array}$ & & \\
\hline Oil Exports/Total Exports (t-1) X Low oil prices (t-1) X Forex Reserves/GDP (log) (t-1) & & $\begin{array}{c}-0.00312^{* *} \\
(0.00154)\end{array}$ & \\
\hline Oil Exports/Total Exports (t-1) X Low oil prices (t-1) & & $\begin{array}{l}0.0111^{* * *} \\
(0.00382)\end{array}$ & \\
\hline Oil Exports/Total Exports (t-1) X Forex Reserves/GDP (log) (t-1) & & $\begin{array}{c}0.00382^{* * *} \\
(0.00115)\end{array}$ & \\
\hline Oil Production/GDP ( $(\mathrm{t}-1) \times$ Low oil prices (t-1) X Forex Reserves/GDP (log) (t-1) & & & $\begin{array}{c}-0.0308^{* *} \\
(0.0125)\end{array}$ \\
\hline Oil Production/GDP ( $\mathrm{t}-1) \mathrm{X}$ Low oil prices ( $\mathrm{t}-1)$ & & & $\begin{array}{l}0.103^{* * *} \\
(0.0324)\end{array}$ \\
\hline Oil Production/GDP (t-1) X Forex Reserves/GDP (log) (t-1) & & & $\begin{array}{c}0.0346^{* * *} \\
(0.0119)\end{array}$ \\
\hline Low oil prices (t-1) X Forex Reserves/GDP (log) (t-1) & $\begin{array}{c}0.0371 \\
(0.0503)\end{array}$ & $\begin{array}{c}0.0768 \\
(0.0541)\end{array}$ & $\begin{array}{c}0.0414 \\
(0.0458)\end{array}$ \\
\hline Oil Rents/GDP (t-1) & $\begin{array}{c}-0.0452^{* * *} \\
(0.0119)\end{array}$ & & \\
\hline Oil Exports/Total Exports (t-1) & & $\begin{array}{c}-0.00853^{* *} \\
(0.00334)\end{array}$ & \\
\hline Oil Production/GDP (t-1) & & & $\begin{array}{c}-0.111^{* * *} \\
(0.0321)\end{array}$ \\
\hline Low Oil prices ( $\mathrm{t}-1)$ & $\begin{array}{c}-1.031^{\star * *} \\
(0.213)\end{array}$ & $\begin{array}{c}-1.100^{* * *} \\
(0.216)\end{array}$ & $\begin{array}{c}-0.948^{* * *} \\
(0.200)\end{array}$ \\
\hline Forex Reserves/GDP (log) (t-1) & $\begin{array}{c}-0.138^{* * *} \\
(0.0426)\end{array}$ & $\begin{array}{c}-0.169^{* \star *} \\
(0.0466)\end{array}$ & $\begin{array}{c}-0.121^{\star * *} \\
(0.0401)\end{array}$ \\
\hline Per capita GDP $(\log )(\mathrm{t}-1)$ & $\begin{array}{c}0.00511 \\
(0.152)\end{array}$ & $\begin{array}{c}0.145 \\
(0.164)\end{array}$ & $\begin{array}{l}-0.0390 \\
(0.133)\end{array}$ \\
\hline Democracy (t-1) & $\begin{array}{c}-0.245^{\star * *} \\
(0.0936)\end{array}$ & $\begin{array}{c}-0.281^{* * *} \\
(0.0935)\end{array}$ & $\begin{array}{l}-0.268^{* * *} \\
(0.0872)\end{array}$ \\
\hline Autocracy $(\mathrm{t}-1)$ & $\begin{array}{l}0.0284 \\
(0.105)\end{array}$ & $\begin{array}{c}-0.00515 \\
(0.106)\end{array}$ & $\begin{array}{c}-0.0589 \\
(0.0948)\end{array}$ \\
\hline Economic Crises (t-1) & $\begin{array}{l}0.234^{* * *} \\
(0.0882)\end{array}$ & $\begin{array}{l}0.228^{* * *} \\
(0.0877)\end{array}$ & $\begin{array}{l}0.233^{* * *} \\
(0.0830)\end{array}$ \\
\hline Population $(\log )(t-1)$ & $\begin{array}{c}0.441 \\
(0.317)\end{array}$ & $\begin{array}{c}0.237 \\
(0.310)\end{array}$ & $\begin{array}{c}0.00667 \\
(0.286)\end{array}$ \\
\hline Trade/GDP (t-1) & $\begin{array}{c}0.00208 \\
(0.00208)\end{array}$ & $\begin{array}{c}0.00297 \\
(0.00202)\end{array}$ & $\begin{array}{c}0.000794 \\
(0.000811)\end{array}$ \\
\hline Civil conflict (t-1) & $\begin{array}{l}0.402^{* * *} \\
(0.0859)\end{array}$ & $\begin{array}{l}0.422^{* * *} \\
(0.0864)\end{array}$ & $\begin{array}{l}0.522^{* * *} \\
(0.0777)\end{array}$ \\
\hline Constant & $\begin{array}{l}-7.419 \\
(5.647) \\
\end{array}$ & $\begin{array}{l}-4.964 \\
(5.556)\end{array}$ & $\begin{array}{l}0.0766 \\
(5.040) \\
\end{array}$ \\
\hline Estimation Technique & NBREG & NBREG & NBREG \\
\hline Pearson goodness-of-fit & $11719^{* * *}$ & $12056^{* * *}$ & $13423^{* * *}$ \\
\hline Hausaman test & 0.001 & 0.001 & 0.001 \\
\hline Country Fixed Effects & Yes & Yes & Yes \\
\hline Year Fixed Effects & Yes & Yes & Yes \\
\hline Number of Countries & 125 & 142 & 151 \\
\hline Total Observations & 3,600 & 3,906 & 4,380 \\
\hline
\end{tabular}

\section{Notes:}

(1) Robust standard errors in parenthesis

(2) Statistical significance: ${ }^{* *} p<0.01, * * p<0.05,{ }^{*} p<0.1$

(3) Negative binomial estimator reports coefficients 
Table 5: Forex Reserves effect - Interactions of oil imports, oil prices and Forex reserves

Protests

Oil Imports/Total Imports (t-1) X High oil prices (t-1) X Forex Reserves/GDP (log) (t-1)

Oil Imports/Total Imports ( $\mathrm{t}-1) \mathrm{X}$ High oil prices ( $\mathrm{t}-1)$

Oil Imports/Total Imports (t-1) X Forex Reserves/GDP (log) (t-1)

$0.0259 * * *$

$(0.00971)$

$-0.000979$

$(0.00468)$

High oil prices ( $\mathrm{t}-1)$ X Forex Reserves/GDP (log) ( $\mathrm{t}-1$ )

0.0179

(0.0824)

Oil Imports/Total Imports ( $\mathrm{t}-1)$

$-0.00814$

(0.00937)

High Oil prices ( $\mathrm{t}-1)$

$0.602 * *$

(0.246)

Forex Reserves/GDP (log) $(\mathrm{t}-1)$

$-0.0492$

(0.0677)

Per capita GDP (log) $(\mathrm{t}-1)$

$-0.0656$

(0.168)

Democracy (t-1)

$-0.303^{* * *}$

(0.0942)

Autocracy (t-1)

0.0749

(0.110)

Economic Crises (t-1)

$0.258^{* * *}$

(0.0891)

Population (log) (t-1)

0.105

(0.325)

0.00299

Trade/GDP (t-1)

(0.00217)

Civil conflict ( $\mathrm{t}-1$ )

$0.445^{* * *}$

(0.0866)

Constant

Estimation Technique NBREG

Pearson goodness-of-fit $12142 * * *$

Hausaman test 0.000

Country Fixed Effects Yes

Year Fixed Effects

Number of Countries

Total Observations

Notes:

(1) Robust standard errors in parenthesis

(2) Statistical significance: ${ }^{* * *} p<0.01,{ }^{* *} p<0.05,{ }^{*} p<0.1$

(3) Negative binomial estimator reports coefficients 
Figure 1: Oil price and Non Violent protests in Oil producing countries

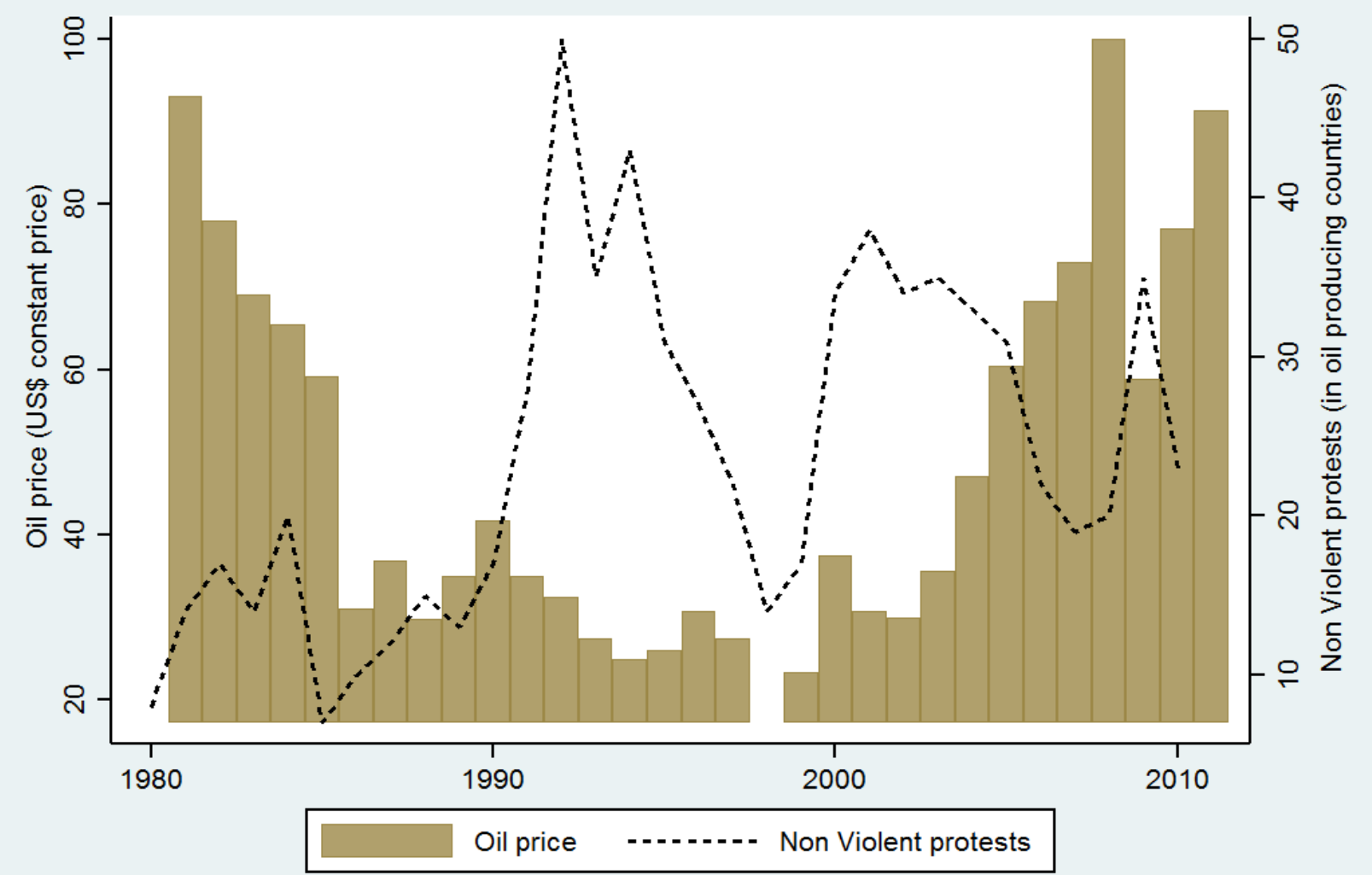

Note: an oil producer is defined as oil exports to GDP greater than $1 / 3^{\text {rd }}$ of total exports 
Figure 2: Oil price and Non Violent protests in Oil consuming countries

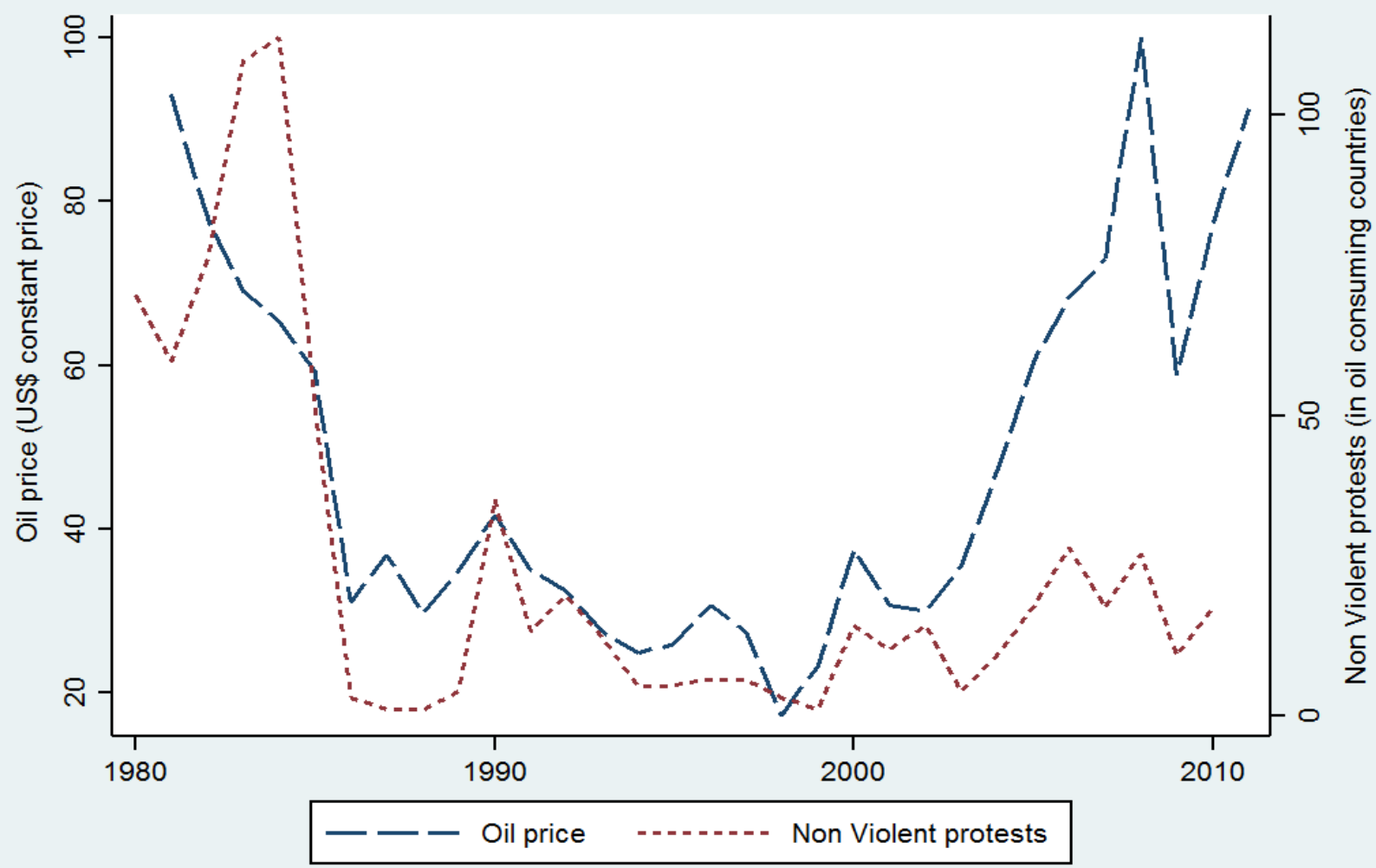

Note: Oil importer is defined as oil imports greater than $25 \%$ of GDP

Figure 3: Low oil prices, Forex Reserves, Oil Rents \& Marginal Effect on Protests

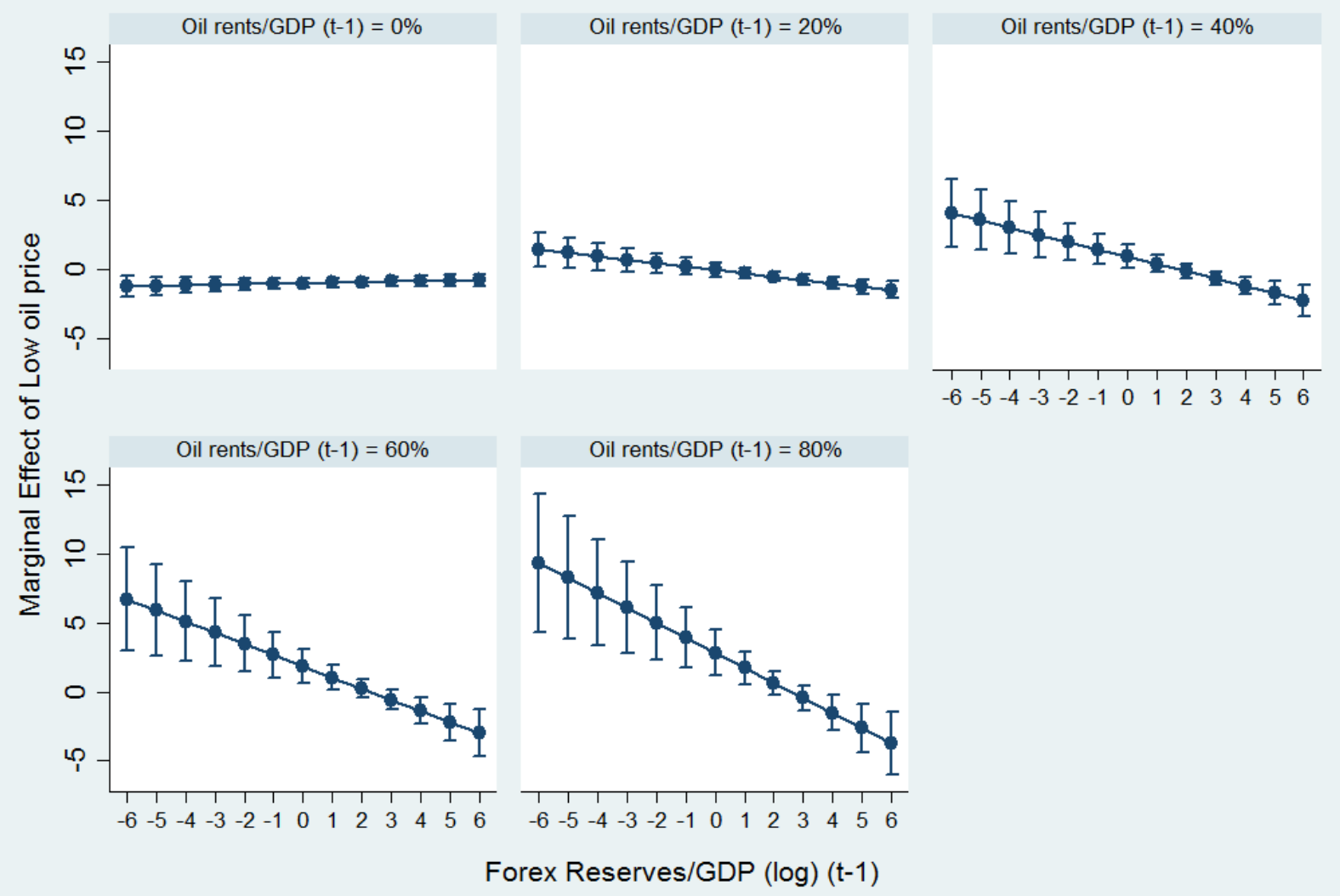


Figure 4: Low oil prices, Forex Reserves, Oil exports \& Marginal Effect on Protests

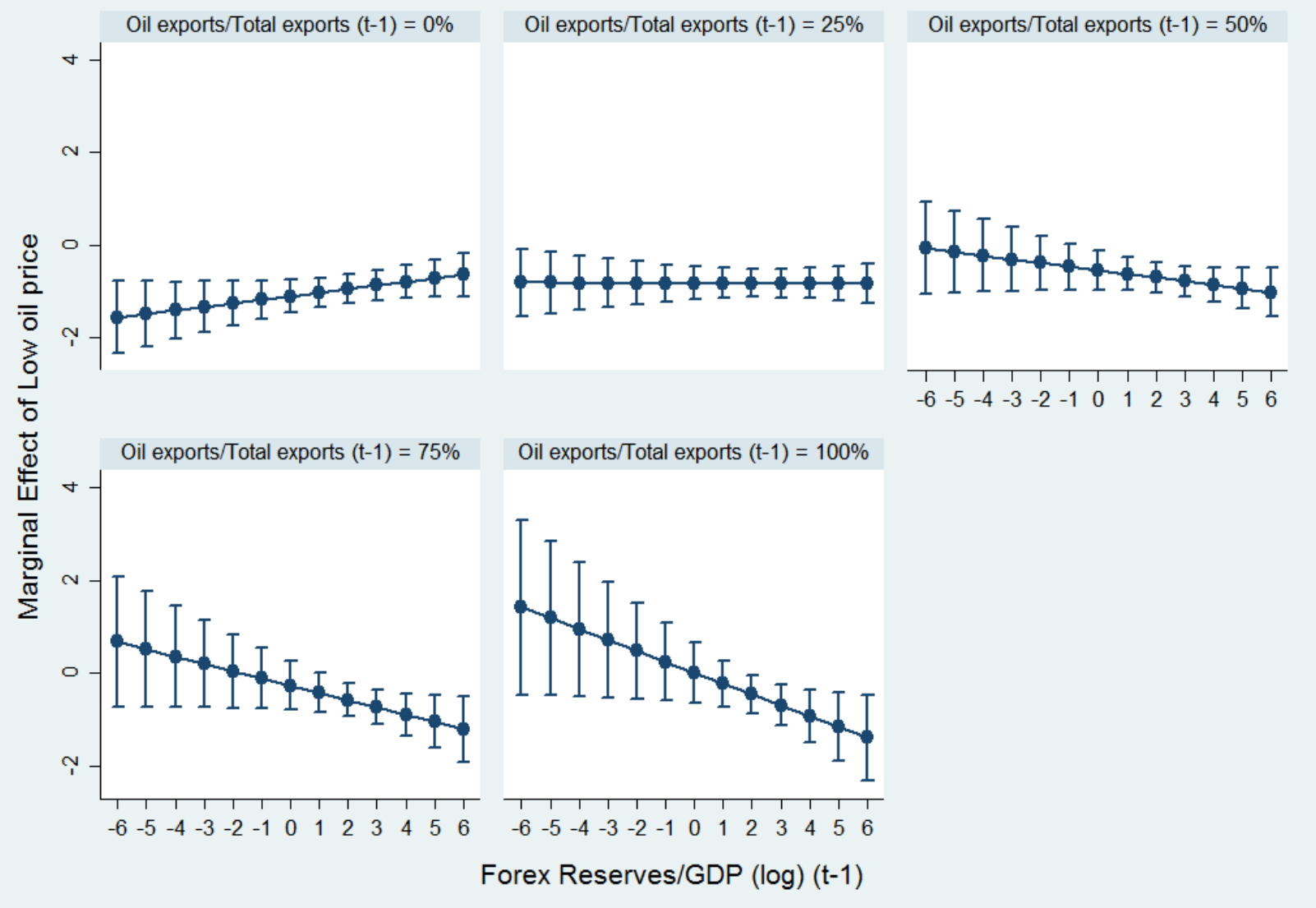


Figure 5: Low oil prices, Forex Reserves, Oil Production \& Marginal Effect on Protests

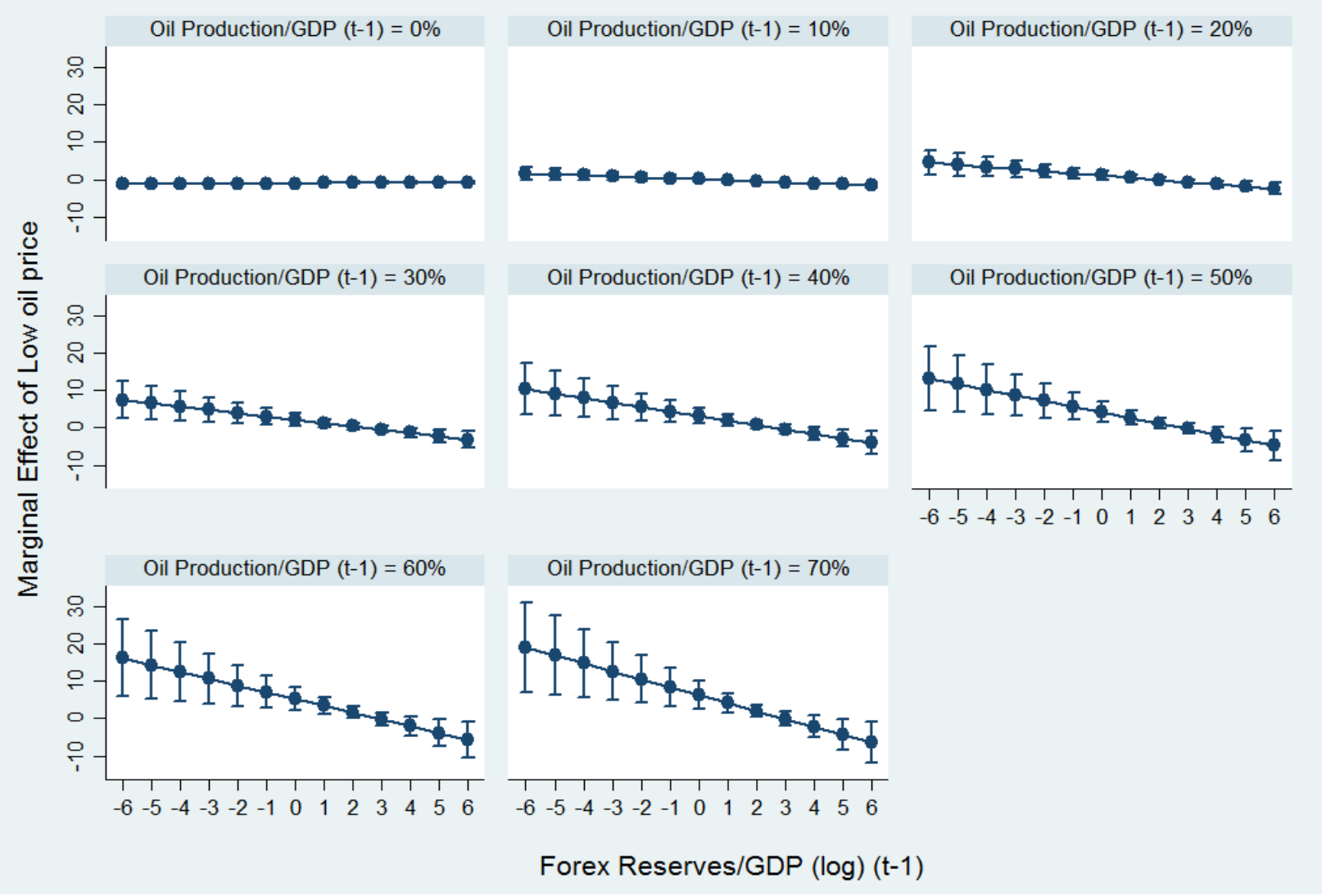


Figure 6: High oil prices, Forex Reserves, Oil Imports \& Marginal Effect on Protests

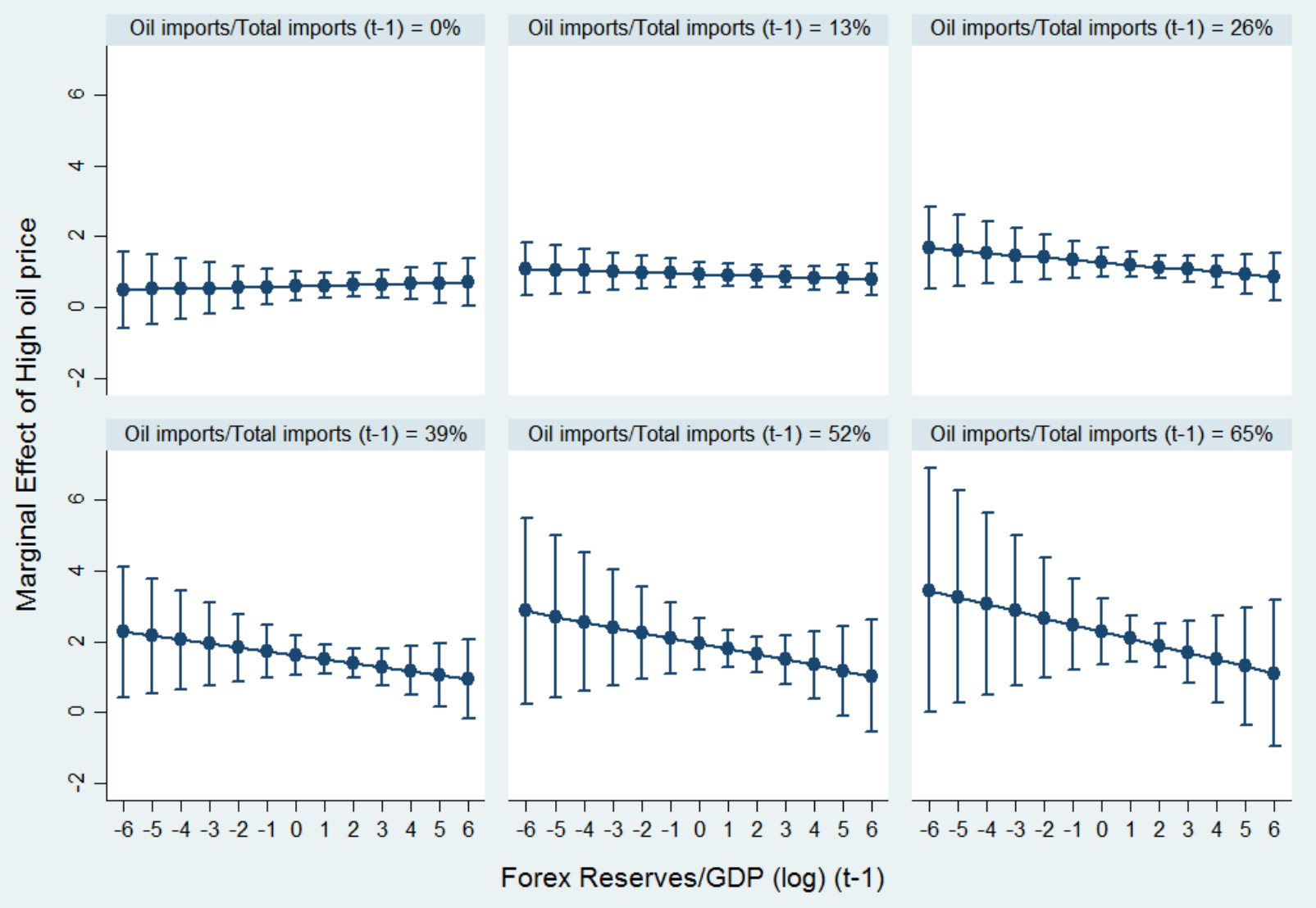




\section{Appendix}

Appendix 1: Countries under study

\begin{tabular}{|c|c|c|c|c|}
\hline Afghanistan & Comoros & Haiti & Mongolia & Slovenia \\
\hline Albania & Congo, Democratic Republic & Honduras & Morocco & Solomon Islands \\
\hline Algeria & Congo, Republic & Hungary & Mozambique & South Africa \\
\hline Angola & Costa Rica & India & Myanmar & South Korea \\
\hline Argentina & Cote d'Ivoire & Indonesia & Namibia & Spain \\
\hline Armenia & Croatia & Iran & Nepal & Sri Lanka \\
\hline Australia & Cuba & Iraq & Netherlands & Sudan \\
\hline Austria & Cyprus & Ireland & New Zealand & Suriname \\
\hline Azerbaijan & Czech Republic & Israel & Nicaragua & Swaziland \\
\hline Bahrain & Denmark & Italy & Niger & Sweden \\
\hline Bangladesh & Djibouti & Jamaica & Nigeria & Switzerland \\
\hline Barbados & Dominican Republic & Japan & North Korea & Syria \\
\hline Belarus & Ecuador & Jordan & Norway & Taiwan \\
\hline Belgium & Egypt & Kazakhstan & Oman & Tajikistan \\
\hline Belize & El Salvador & Kenya & Pakistan & Tanzania \\
\hline Benin & Equatorial Guinea & Kuwait & Panama & Thailand \\
\hline Bhutan & Eritrea & Kyrgyz Republic & Papua New Guinea & Togo \\
\hline Bolivia & Estonia & Laos & Paraguay & Trinidad and Tobago \\
\hline Botswana & Ethiopia & Latvia & Peru & Tunisia \\
\hline Brazil & Fiji & Lebanon & Philippines & Turkey \\
\hline Brunei & Finland & Lesotho & Poland & Turkmenistan \\
\hline Bulgaria & France & Liberia & Portugal & Uganda \\
\hline Burkina Faso & Gabon & Libya & Qatar & Ukraine \\
\hline Burundi & Gambia & Lithuania & Romania & United Arab Emirates \\
\hline Cambodia & Georgia & Macedonia & Russia & United Kingdom \\
\hline Cameroon & Germany & Madagascar & Rwanda & United States of America \\
\hline Canada & Ghana & Malawi & Sao Tome and Principe & Uruguay \\
\hline Cape Verde & Greece & Malaysia & Saudi Arabia & Uzbekistan \\
\hline Central African Republic & Grenada & Mali & Senegal & Venezuela \\
\hline Chad & Guatemala & Mauritania & Seychelles & Vietnam \\
\hline Chile & Guinea & Mauritius & Sierra Leone & Yemen \\
\hline China & Guinea-Bissau & Mexico & Singapore & Zambia \\
\hline Colombia & Guyana & Moldova & Slovakia & Zimbabwe \\
\hline
\end{tabular}


Appendix 2: Descriptive statistics

\begin{tabular}{lccccc}
\hline \multicolumn{1}{c}{ Variables } & Mean & Standard Deviation & Minimum & Maximum & Observations \\
\hline Anti-government Protests & 1.26 & 3.88 & 0.00 & 82.00 & 5367 \\
Oil Exports/Total Exports & 18.47 & 29.06 & 0.00 & 100.00 & 4409 \\
Oil Rents/GDP & 6.08 & 12.63 & 0.00 & 80.24 & 4115 \\
Oil Production/GDP & 2.53 & 6.26 & 0.00 & 70.59 & 4864 \\
Oil Imports/Total Imports & 13.6132 & 9.40 & 0.00 & 64.14 & 4271 \\
Low Oil price & 0.50 & 0.50 & 0.00 & 1.00 & 5610 \\
High Oil price & 0.50 & 0.50 & 0.00 & 1.00 & 5610 \\
Forex Reserves/GDP & 13.29 & 15.90 & -0.45 & 302.01 & 5116 \\
Forex Reserves/GDP $(\log )$ & 2.01 & 1.27 & -14.93 & 5.71 & 5115 \\
Per capita GDP $(\log )$ & 7.82 & 1.62 & 4.32 & 11.27 & 5347 \\
Democracy & 0.46 & 0.50 & 0.00 & 1.00 & 5096 \\
Autocracy & 0.30 & 0.46 & 0.00 & 1.00 & 5096 \\
Economic crises & 0.07 & 0.25 & 0.00 & 1.00 & 5462 \\
Population $(\log )$ & 15.86 & 1.70 & 11.07 & 21.06 & 5542 \\
Trade/GDP & 62.43 & 42.66 & 4.91 & 986.65 & 5319 \\
Civil conflict & 0.17 & 0.38 & 0.00 & 1.00 & 5400 \\
\hline
\end{tabular}




\section{Appendix 3: Data definition and sources}

\begin{tabular}{|c|c|}
\hline Variables & Data definition and sources \\
\hline Anti-government protests & $\begin{array}{l}\text { Count measure of anti-government protests in country } i \text { in year } t \text { in the form of } \\
\text { riots, anti-government demonstrations, sourced from Banks and Kenneth (2015) }\end{array}$ \\
\hline Low oil prices & $\begin{array}{l}\text { Dummy which takes the value } 1 \text { if inflation adjusted oil price in year } t \text { is below the } \\
\text { median value of oil price during } 1980-2013 \text { and } 0 \text { otherwise. }\end{array}$ \\
\hline High oil prices & $\begin{array}{l}\text { Dummy which takes the value } 1 \text { if inflation adjusted oil price in year } t \text { is above the } \\
\text { median value of oil price during } 1980-2013 \text { and } 0 \text { otherwise. }\end{array}$ \\
\hline Oil rents (share of GDP) & $\begin{array}{l}\text { Oil rents defined as the unit price minus the cost of production times the quantity } \\
\text { produced and is divided by GDP. Sourced from World Development Indicators } \\
2016 \text {, World Bank. }\end{array}$ \\
\hline Oil exports (share of exports) & $\begin{array}{l}\text { Oil exports as a share of total exports is sourced from World Development } \\
\text { Indicators 2016, World Bank. }\end{array}$ \\
\hline Oil imports (share of imports) & $\begin{array}{l}\text { Oil imports as a share of total imports is sourced from World Development } \\
\text { Indicators 2016, World Bank. }\end{array}$ \\
\hline Oil production (share of GDP) & $\begin{array}{l}\text { Oil production data is obtained by disaggregating the oil rents variable into oil } \\
\text { production and price parts developed by Ross (2012) and Haber and Mehaldo } \\
\text { (2012) taken as a share of GDP }\end{array}$ \\
\hline Per capita GDP (log) & $\begin{array}{l}\text { GDP per head in } 2000 \text { US\$ constant prices sourced from World Development } \\
\text { Indicators 2016, World Bank. }\end{array}$ \\
\hline Population (log) & $\begin{array}{l}\text { Count of total population (log) sourced from World Development Indicators 2015, } \\
\text { World Bank. }\end{array}$ \\
\hline Democracy & $\begin{array}{l}\text { Based on Polity IV index (coded on }-10 \text { to }+10 \text { scale) we recode the original Polity } \\
\text { index as democracy dummy which takes the value of } 1 \text { of Polity score is above }+6 \\
\text { and } 0 \text { otherwise. }\end{array}$ \\
\hline Autocracy & $\begin{array}{l}\text { Based on Polity IV index (coded on }-10 \text { to }+10 \text { scale) we recode the original Polity } \\
\text { index as autocracy dummy which takes the value of } 1 \text { of Polity score is below }-5 \\
\text { and } 0 \text { otherwise. }\end{array}$ \\
\hline Economic crisis & $\begin{array}{l}\text { Coded the value } 1 \text { if country } i \text { in year } t \text { faced with either debt, currency and } \\
\text { banking crisis and } 0 \text { otherwise sourced from Laeven and Valencia (2013) }\end{array}$ \\
\hline Trade Openness & $\begin{array}{l}\text { Total exports and imports as a share of GDP sourced from UNCTAD statistics } \\
2016 .\end{array}$ \\
\hline Forex reserves/GDP (log) & $\begin{array}{l}\text { Total accumulated foreign exchange reserves as a share of GDP logged Sourced } \\
\text { from World Development Indicators 2016, World Bank. }\end{array}$ \\
\hline Civil conflict & $\begin{array}{l}\text { Dummy coded } 1 \text { for each year a country has at least one active conflict with } 25 \\
\text { battle deaths and } 0 \text { otherwise obtained from Uppsala Conflict Data Program, } 2016\end{array}$ \\
\hline
\end{tabular}




\section{References}

Acemoglu, Daron and James Robinson. 2012. Why Nations Fail: The Origins of Power, Prosperity and Poverty. New York: Crown Publishers.

Achen, Christopher H. 2005. "Let'S Put the Garbage-Can Regressions and Garbage-Can Probits Where They Belong." Conflict Management and Peace Science 22:327-39.

Ai, C. and E. Norton. 2003. "Interaction Terms in Logit and Probit Models." Economics Letters 80:123-29.

Arezki, Rabah, Adnan Mzarei and Ananthakrishnan Prasad. 2015. "Sovereign Wealth Funds in the New Era of Oil." iMF Direct https://blogimfdirect.imf.org/2015/10/26/sovereign-wealth-funds-in-the-new-era-ofoil/ (last accessed Jan 2017).

Auty, Richard M. 2000. "How Natural Resources Affect Economic Development." Development Policy Review 18:347-64.

Auty, Richard M. and Alan H. Gelb. 2000. "Political Economy of Resource Abundant States." Vol.

Auty, Richard M. . 2001. "Resource Abundance and Economic Development." Pp. 3-18 in Unu/Wider Studies in Development Economics. Oxford: Oxford University Press.

Baig, Taimur, Amine Mati, David Coady and Joseph Ntamatungiro. 2007. "Domestic Petroleum Product Prices and Subsidies: Recent Developments and Reform Strategies." IMF working paper WP/07/71 March(https://www.imf.org/external/pubs/ft/wp/2007/wp0771.pdf (last accessed Jan 2017)).

Bank, Andre, Thomas Richter and Anna Sunik. 2013. "Long-Term Monarchical Survival in the Middle East: A Configurational Comparison, 1945-2012." Demoratization 22(1):179-200.

Banks, Arthur S., Wilson, Kenneth A. 2017. "Cross-National Time-Series Data Archive. Databanks International." Jerusalem, Israel; Available at: https://www.cntsdata.com/

Basedau, Matthias and Jann Lay. 2009. "Resource Curse or Rentier Peace? The Ambiguous Effects of Oil Wealth and Oil Dependence on Violent Conflict." Journal of Peace Research 46(6):757-76.

Bates, Robert H., ed. 1988. Toward a Political Economy of Development: A Rational Choice Perspective. Berkeley: University of California Press.

Bazzi, Samuel and Christopher Blattman. 2014. "Economic Shocks and Con Ict: Evidence from Commodity Prices." American Economic Journal: Macroeconomics 6(4):1-38. 
Beck, Nathaniel and Jonathan N. Katz. 1996. "Nuisance Vs. Substance: Specifying and Estimating Time-Series-Cross-Section Models." Political Analysis 6:136.

Bodea, Christina, Masaaki Higashijima and Raju Jan Singh. 2016. "Oil and Civil Conflict: Can Public Spending Have a Mitigation Effect?". World Development 78(February):1-12.

Bohlken, Anjali T. and Ernest J. Sergenti. 2010. "Economic Growth and Ethnic Violence: An Empirical Investigation of Hindu-Muslim Riots in India." Journal of Economic Growth 47(5):589-600.

Bound, John, David A. Jaeger and Regina M. Baker. 1995. "Problems with Instrumental Variables Estimation When the Correlation between the Instruments and the Endogenous Explanatory Variable Is Weak." Journal of the American Statistical Association 90(430):443-50.

Brandt, Patrick T., John T. Williams, Benjamin O. Fordham, and Brian Pollins. 2000. "Dynamic Models for Persistent Event Count Time Series." American Journal of Political Science 44(4):823-843

Brahmbhatt, Milan and Otaviano Canuto. 2010. "Natural Resources and Development Strategy after the Crisis." Economic Premise February(1):http://siteresources.worldbank.org/EXTPREMNET/Resources /Economic Premise1.pdf (last accessed Jan 2017).

Brazys, S. 2010. "Dutch Disease in the Western Pacific: an overview of the FSM economy under the Amended Compact of Free Association." Pacific Economic Bulletin, 25(3): 24-39

Brown, Stephen P. A., Mine K. Yucel and John Thompson. 2003. "Business Cycles: The Role of Energy Prices." Federal Reserve Bank of Dallas working paper 0304(https://www.dallasfed.org/ /media/documents/.../wp0304.pdf (last accessed Jan 2017)).

Brückner, Markus and Antonio Ciccone. 2010. "International Commodity Prices, Growth and the Outbreak of Civil War in Sub-Saharan Africa." The Economic Journal 120(544):519-34.

Brunnschweiler, Christa N. and Erwin H. Bulte. 2009. "Natural Resources and Violent Conflict: Resource Abundance, Dependence, and the Onset of Civil Wars." Oxford Economic Papers 61(4):651-74.

Bueno de Mesquita, Bruce and Hilton L. Root. 2000. "When Bad Economics is Good Politics." Pp. 1-16 in Governing for Prosperity, edited by B. Bueno de Mesquita and H. L. Root. New Haven, CT: Yale University Press.

Bueno de Mesquita, Bruce and Alistair Smith. 2011. The Dictator'S Handbook: Why Bad Behaviour Is Almost Always Good Politics. New York: PublicAffairs. 
Buhaug, Halvard et al. 2014. "One Effect to Rule Them All? A Comment on Climate and Conflict." Climate Change 127(3):391-97.

Bulte, Erwin H., Richard Damania and Robert T. Deacon. 2005. "Resource Intensity, Institutions, and Development." World Development 33(7):1029-44.

Burke, Paul J. 2012. "Economic Growth and Political Survival." The B.E. Journal of Macroeconomics 12(1):online: https://doi.org/10.1515/935-690.2398.

Bussmann, Margit, Harald Scheuthle and Gerald Schneider. 2005. "Trade Liberalization and Political Instability in Developing Countries." Pp. 49-70 in Programming for Peace: Computer-Aided Methods for International Conflict Resolution and Prevention, edited by R. Trappl. Dordrecht: Kluwer.

Cameron, Colin A. and Pravin K. Trivedi. 2013. Regression Analysis of Count Data, Edited by n. Edition. Cambridge: Cambridge University Press.

Cantore, Nocola, Allessandro Antimiani and Paolo Rui Anciaes. 2012. "Energy Price Shocks: Sweet and Sour Consequences for Developing Countries." Overseas Development Institute, Working paper 355 August(https://www.odi.org/sites/odi.org.uk/files/odiassets/publications-opinion-files/7794.pdf (last accessed Jan 2017)).

Cawthorne, Andrew and Alexandra Ulmer. 2016. "Venezuela Protests against Maduro Escalate, Dozens Injured." Reuters: World News October, 27 (http://www.reuters.com/article/us-venezuela-politicsidUSKCN12Q0B6 (last Accessed Jan 2017)).

Chassang, Sylvain and Gerard Padró i Miquel. 2009. "Economic Shocks and Civil War." Quarterly Journal of political Science 4(3):211-28.

Chenoweth, Erica and Maria J. Stephan. 2011. Why Civil Resistance Works: The Stategic Logic of Nonviolent Conflict. New York: Columbia University Press.

Chenoweth, Erica and Jay Ulfelder. 2017. "Can Structural Conditions Explain the Onset of Nonviolent Uprisings?". Journal of Conflict Resolution 61(2):298324.

Cheon, Andrew, Johannes Urpelainen and Maureen Lackner. 2013. "Why Do Governments Subsidize Gasoline Consumption? An Empirical Analysis of Global Gasoline Prices, 2002-2009." Energy Policy 56(May):382-90.

Collier, Paul and Anke Hoeffler. 2004. "Greed and Grievance in Civil War." Oxford Economic Papers 56(4):563-95.

Collier, Paul and Dominic Rohner. 2008. "Democracy, Development and Conflict." Journal of the European Economic Association 6(2-3):531-40.

Collier, Paul, Anke Hoeffler and Dominic Rohner. 2009. "Beyond Greed and Grievance: Feasibility and Civil War." Oxford Economic Papers 61(1):1-27. 
Costello, Matthew, Craig J. Jenkins and Hassan Aly. 2015. "Bread, Justice, or Opportunity? The Determinants of the Arab Awakening Protests." World Development 67:90-100.

Devlin, Julia and Michael Lewin. 2005. "Managing Oil Booms and Busts in Developing Countries." Pp. 186-212 in Managing Economic Volatility and Crises: A Practitioner'S Guide, edited by J. Eizenman and B. Pinto. Cambridge: Cambridge University Press \& The World Bank.

Diamond, Larry. 2008. The Spirit of Democracy: The Struggle to Build Free Societies Throughout the World. New York: Henry Holt.

Doğrul, Günsel H. and Ugur Soytas. 2010. "Relationship between Oil Prices, Interest Rate, and Unemployment: Evidence from an Emerging Market." Energy Economics 32:1523-28.

Dreher, Axel and Martin Gassebner. 2012. "Do Imf and World Bank Programs Induce Government Crises? An Empirical Analysis." International Organization 66(2):329-58.

Dube, Oeindrila and Juan Vargas. 2013. "Commodity Price Shocks and Civil Conflict: Evidence from Colombia." Review of Economic Studies 80(4):1384-421.

Eifert, Benn, Alan Gelb and Nils Borje Tallroth. 2003. "Managing Oil Wealth." Finance and Development 40(1):http://www.imf.org/external/pubs/ft/fandd/2003/03/eife.htm (last accessed Jan 17).

Fearon, James D. and David D. Laitin. 2003. "Ethnicity, Insurgency, and Civil War." American Political Science Review 97(1):1-16.

Fearon, James D. 2005. "Primary Commodities Exports and Civil War." Journal of Conflict Resolution 49(4):483-507.

Frankel, Jeffrey A. 2012. "The Natural Resource Curse: A Survey of Diagnoses and Some Prescriptions." Vol. HKS Faculty Research Working Paper Series RWP12-014. Boston, MA: John F. Kennedy School of Government, Harvard University.

Gary, lan and Terry Lynn Karl. 2003. Bottom of the Barrel: Africa's Oil Boom and the Poor, Vol. http://www.crs.org/sites/default/files/toolsresearch/bottom-of-the-barrel.pdf (last accessed Jan 2017): Catholic Relief Services.

Gleditsch, Nils Petter, Peter Wallensteen, Mikael Eriksson, Margareta Sollenberg and Haavard Strand. 2002. "Armed Conflict 1946-2001: A New Dataset." Journal of Peace Research 39(5):615-37.

Goldstone, Jack A., Robert H. Bates, David L. Epstein, Ted R. Gurr, Michael B. Lustik, Monty G. Marshall, Jay Ulfelder and Mark Woodward. 2010. "A 
Global Model for Forecasting Political Instability." American Political Science Review 54(1):190-208.

Gupte, Jaideep, Patricia Justino and Jean-Pierre Tranchant. 2014. "Households Amid Urban Riots: The Economic Consequences of Civil Violence in India." Journal of Conflict Resolution 58(8):1445-73.

Haber, Stephen, and Victor A. Menaldo. 2010. "Do Natural Resources Fuel Authoritarianism? A Reappraisal of the Resource Curse." American Political Science Review 105(1): 1-24

Hamilton, James D. 2000. "What Is an Oil Shock?". NBER working paper 7755 June(http://www.nber.org/papers/w7755 (last accessed Jan 2017)).

Hamilton, James D. 2008. "Understanding Crude Oil Prices." NBER working paper 14492 November(http://www.nber.org/papers/w14492 (last accessed Jan 2017)).

Hegre, Havard, Ranveig Gissinger and Nils Petter Gleditsch. 2003. "Globalization and Internal Conflict." Pp. 251-75 in Globalization and Armed Conflict, edited by G. Schneider, K. Barbieri and N. P. Gleditsch. Lanham, MD: Rowman \& Littlefield.

Hendrix, Cullen and Stephan Haggard. 2015. "Global Food Prices, Regime Type, and Urban Unrest in the Developing World." Journal of Peace Research 52(2):143-57.

Hunt, Ben, Peter Isard and Douglas Laxton. 2001. "The Macroeconomic Effects of Higher Oil Prices." IMF working paper WP/01/14 https://www.imf.org/external/pubs/ft/wp/2001/wp0114.pdf $\quad$ (last accessed Jan 2017).

Husain, Aasim M., Rabah Arezki, Peter Breuer, Vikram Haksar, Thomas Helbling, Paulo Medas, Martin Sommer and Staff Team IMF. 2015. "Global Implications of Lower Oil Prices." Vol. SDN 15/15. IMF staff discussion note. Washington, DC: International Monetary Fund.

Jiménez-Rodríguez, Rebeca and Marcelo Sanchez. 2005. "Oil Price Shocks and Real Gdp Growth: Empirical Evidence for Some Oecd Countries." Applied Economics 37(2):201-28.

Karl, Terry Lynn. 1997. The Paradox of Plenty: Oil Booms and Petro-States. Berkeley, CA: University of California Press.

Klare, Micheal T. 2016. "The Hidden Risk of Plummeting Oil Prices: War." The Nation.

Krugman, Paul. 2016. "Oil Goes Nonlinear." The New York Times http://krugman.blogs.nytimes.com/2016/01/16/oil-goes-nonlinear/? $r=0$ (last accessed: Jan 2017).

Kuran, Timur. 1995. Private Truths, Public Lies: The Social Consequences of Preference Falsification. Cambridge, MA: Harvard University Press. 
Laeven, Luc and Fabian Valencia. 2013. "Systemic Banking Crises Database." IMF Economic Review 61(2):225-70.

Lane, Philip R. and Aaron Tornell. 1996. "Power, Growth, and the Voracity Effect." Journal of Economic Growth 1(June):213-41.

Lawless, Jerald F. 1987. "Negative Binomial and Mixed Poisson Regression." Canadian Journal of Statistics 15(3):209-25.

Le Billion, Philippe. 2001. "The Political Ecology of War: Natural Resources and Armed Conflict." Political Geography 20(5):561-84.

Le Billon, Philippe, ed. 2005. The Geopolitics of Resource Wars: Resource Dependence, Governance, and Violence. London: Routledge.

Lipton, Michael. 1976. Why Poor People Stay Poor: A Study of Urban Bias in World Development. Cambridge, MA: Harvard University Press.

Lujala, Paivi. 2010. "The Spoils of Nature: Armed Civil Conflict and Rebel Acess to Natural Resources." Journal of Peace Research 47(1):15-28.

Mahdavy, Hossein. 1970. "The Pattern and Problems of Economic Development in Rentier States: The Case of Iran." in Studies in the Economic History of the Middle East, edited by M. A. Cook. Oxford: Oxford University Press.

Manzano, Osmel and Roberto Rigobon. 2001. "Resource Curse or Debt Overhang?". NBER working $\quad 8390$ July(http://www.nber.org/papers/w8390 (last accessed Jan 2017)).

Marshall, Monty G., and Jaggers, Keith. 2002. Polity IV Project: Political Regime Characteristics and Transitions, 1800-2000. College Park: University of Maryland.

Mehlum, Halvor, Karl Moene and Ragnar Torvik. 2006. "Cursed by Resources or Institutions?". The World Economy 10:1117-31.

Meyersson, Erik, Gerard Padro i Miguel and Nancy Qian. 2008. "The Rise of China and the Natural Resource Curse in Africa." Working paper, Kellogg School of Management Northwestern University.

Miguel, Edward, Shanker Satyanath and Ernest Sergenti. 2004. "Economic Shocks and Civil Conflict: An Instrumental Variables Approach." Journal of Political Economy 112(4):725-53.

Morgan, Richard K. and Eric Reinhardt. 2015. "Commodity Price Volatility and Civil Conflict." Emory University, Atlanta, GA.

Olson, Mancur. 1965. The Logic of Collective Action. Cambridge, MA: Harvard University Press.

Rasmussen, Tobias N. and Agustin Roitman. 2011. "Oil Shocks in a Global Perspective: Are They Really That Bad?". IMF working paper WP/11/194 August(https://papers.ssrn.com/sol3/papers.cfm?abstract id=1910497 (last accessed Jan 2017)). 
Regan, Patrick and Daniel Norton. 2005. "Greed, Grievance and Mobilization in Civil Wars." Journal of Conflict Resolution 49(3):319-36.

Regnier, Eva. 2007. "Oil and Energy Price Volatility." Energy Economics 29(3):40527.

Robertson, Graeme B. and Emmanuel Teitelbaum. 2011. "Foreign Direct Investment, Regime Type, and Labor Protest in Developing Countries

Authors." American Journal of Political Science 55(3):665-77.

Robinson, James, Ragnar Torvik and Thierry Verdier. 2006. "Political Foundations of the Resource Curse." Journal of Development Economics 79:447-68.

Rogowski, Ronald. 1987. "Political Cleavages and the Changing Exposure to Trade." American Political Science Review 81(4):1121-37.

Ross, Michael. 2006. "A Closer Look at Oil, Diamonds, and Civil War." Annual Review of Political Science 9:265-300.

Ross, Michael L. 1999. "The Political Economy of the Resource Curse." World Politics 51(2):297-332.

Ross, Michael L. 2001. "Does Oil Hinder Democracy?". World Politics 53(3):32561.

Ross, Michael L. 2011. "Will Oil Drown the Arab Spring: Democracy and the Resource Curse." Foreign Affairs 90:2-7.

Ross, Michael L. 2012. The Oil Curse: How Petroleum Wealth Shapes the Development of Nations. Princeton, NJ: Princeton University Press.

Ross, Michael L. 2015. "What Have We Learned About the Resourse Curse?". Annual Review of Political Science TBA.

Sachs, Jeffrey D. and Andrew Warner. 1995. "Natural Resource Abundance and Economic Growth." Vol. NBER Working Paper \# 5318. Cambridge, MA: National Bureau of Economic Research.

Schrodt, Philip A. 2014. "Seven Deadly Sins of Contemporary Quantitative Political Analysis." Journal of Peace Research 51(2):287-300.

Skocpol, Theda. 1979. States and Social Revolutions: A Comparative Analysis of France, Russia, and China. Cambridge: Cambridge University Press.

Smith, Benjamin. 2004. "Oil Wealth and Regime Survival in the Developing World, 1960-1999." American Journal of Political Science 48(2):232-46.

Smith, James L. 2009. "World Oil: Market or Mayhem?". Journal of Economic Perspectives 23(3):145-64.

Thies, Cameron. 2010. "Of Rulers, Rebels, and Revenue: State Capacity, Civil War Onset, and Primary Commodities." Journal of Peace Research 47(3):32132.

Tilly, Charles. 2006. Regimes and Repertoires. Chicago, IL: University of Chicago Press. 
Vadlamannati, Krishna Chaitanya and Indra de Soysa. 2018 (forthcoming). "Do Resource-Wealthy Rulers Adopt Transparency-Promoting Laws? An Empirical Analysis." International Studies Quarterly.

van der Ploeg, Frederick. 2011. "Natural Resources: Curse or Blessing?". Journal of Economic Literature 49(2):366-420.

van Weezel, Stijn. 2016. "Food Imports, International Prices and Violence in Africa." Oxford Economic Papers 68(3):758-81.

Waldner, David. 1999. State Building and Late Development. Ithaca, NY: Cornell University Press.

Watts, Michael 2005. "Resource Curse? Governmentality, Oil and Power in the Niger Delta, Nigeria." Pp. 50-79 in The Geopolitics of Resource Wars: Resource Dependence, Governance and Violence, edited by P. Le Billon. London: Routledge.

Wenar, Leif. 2016. Blood Oil: Tyrants, Violence, and the Rules That Run the World. Oxford: Oxford University Press.

World Bank. 2016, "World Development Indicators: Online Database" http://data.worldbank.org/data-catalog/world-development-indicators. August 14, 2016. 